\title{
Unraveling the Role of Public Researcher Mobility for Industrial Innovation
}

Kongsted, Hans Christian; Kaiser, Ulrich; Ejsing, Ann-Kathrine

Publication date:

2011

Document version

Early version, also known as pre-print

Citation for published version (APA):

Kongsted, H. C., Kaiser, U., \& Ejsing, A-K. (2011). Unraveling the Role of Public Researcher Mobility for Industrial Innovation. Institute for the Study of Labor (IZA). http://ftp.iza.org/dp5691.pdf 
IZA DP No. 5691

Unraveling the Role of Public Researcher Mobility for Industrial Innovation

Ann-Kathrine Ejsing

Ulrich Kaiser

Hans Christian Kongsted

May 2011 


\title{
Unraveling the Role of Public Researcher Mobility for Industrial Innovation
}

\author{
Ann-Kathrine Ejsing \\ The Danish Insurance Association \\ Ulrich Kaiser \\ University of Zurich, CEBR, ZEW and IZA \\ Hans Christian Kongsted \\ University of Copenhagen, CEBR and CAM
}
Discussion Paper No. 5691
May 2011

IZA

P.O. Box 7240

53072 Bonn

Germany

Phone: +49-228-3894-0

Fax: +49-228-3894-180

E-mail: iza@iza.org

Any opinions expressed here are those of the author(s) and not those of IZA. Research published in this series may include views on policy, but the institute itself takes no institutional policy positions.

The Institute for the Study of Labor (IZA) in Bonn is a local and virtual international research center and a place of communication between science, politics and business. IZA is an independent nonprofit organization supported by Deutsche Post Foundation. The center is associated with the University of Bonn and offers a stimulating research environment through its international network, workshops and conferences, data service, project support, research visits and doctoral program. IZA engages in (i) original and internationally competitive research in all fields of labor economics, (ii) development of policy concepts, and (iii) dissemination of research results and concepts to the interested public.

IZA Discussion Papers often represent preliminary work and are circulated to encourage discussion. Citation of such a paper should account for its provisional character. A revised version may be available directly from the author. 


\section{ABSTRACT \\ Unraveling the Role of Public Researcher Mobility for Industrial Innovation*}

We estimate the relative contribution of mobile scientists who leave academia for the private sector on the subsequent innovative performance of the firms they join. We use data on the population of Danish firms and their R\&D workers for the period 1999-2004 and measure innovation performance by the (value-adjusted) number of patent applications at the European Patent Office. We compare the efficacy of mobile former university scientists to the effects of mobile workers hired from other firms as well as immobile workers on the innovation performance of their employer. Our main result is that mobile university scientists contribute substantially more to innovation than R\&D workers hired from other firms who, in turn, contribute slightly less to industrial innovation than recent university graduates. By contrast, immobile workers add little to the innovative activity of their employer. We also find that the contribution of mobile R\&D workers to innovation depreciates fairly rapidly. These findings provide us with three main managerial implications: Firstly, hiring scientists from universities is a way of boosting a firm's innovative activity. Secondly, because hires from academia receive lower wages on average than hires from private sector firms, this implies that hiring R\&D workers from academia may be a cost-effective way of improving innovation performance. Thirdly, firms need to take measures in order to further public-private researcher interaction to prevent the depreciation of the knowledge stock of their employees.

JEL Classification: $\quad$ O33, O34, C23

Keywords: labor mobility, technology transfer, innovation, patents

Corresponding author:

Ulrich Kaiser

University of Zurich

Department of Business Administration

Plattenstr. 14

8032 Zurich

Switzerland

E-mail: ulrich.kaiser@business.uzh.ch

\footnotetext{
* Financial support from Economic Policy Research Network (EPRN) is gratefully acknowledged. We are also indebted to Cédric Schneider for sending us a ready-to-use patent citations database. A large part of this paper was written while Hans Christian Kongsted was on sabbatical leave at Oxford University whom he thanks for the hospitality and the stimulating academic working environment. We gratefully acknowledge helpful comments received at a seminar presentation at KU Leuven. We particularly benefited from comments from Steve Bond, Colin Cameron, Bruno Cassiman, Dirk Czarnitzki, Bruno S. Frey, Christoph Grimpe, Georg Licht, Malwina Mejer, Margit Osterloh, Cédric Schneider, Susanne Thorwarth and Reinhilde Veugelers. The usual disclaimer applies.
} 


\section{Introduction}

Innovation has been hallmarked as a source of sustainable competitive advantage ever since Clark (1987) and Porter (1985). Consequently, management scholars have extensively studied the drivers of firms' innovative performance. A recent and rapidly emerging strand of the literature focuses on labor mobility as a source of knowledge spillovers and innovative capacity (Almeida and Kogut 1999; Corredoira and Rosenkopf 2010; Dietz and Bozeman 2005; Dokko and Rosenkopf 2010; Groysberg et al. forthcoming; Hoisl 2007, 2009; Porter Liebeskind et al. 1996; Kaiser et al. 2008; Kim and Marschke 2005; Maliranta et al. 2009; Rosenkopf and Almeida 2003; Salter and Martin 2001; Saxenian 1994; Singh and Agrawal 2010; Song et al. 2003). ${ }^{1}$

Another body of research is concerned with the role of publicly funded research as a driver of private sector innovation and productivity. The literature distinguishes between "formal" arrangements like joint patenting and licensing (Crespi et al. 2007; Jensen and Thursby 2001; Thursby and Kemp 2002; Thursby and Thursby 2002), public-private research partnerships (Adams et al. 2001; Agrawal and Henderson 2002; Audretsch and Stephan 1996; Cassiman et al. 2008, 2011; Cassiman and Veugelers 2005; Link and Scott 2005; Mansfield 1991), technology transfer offices (Bozeman, 2000; Feldman et al. 2002; Friedman and Silberman 2003; Siegel and Phan 2005; Siegel et al. 2003, 2004; Zucker et al. 2002a) or academic entrepreneurship (Rothaermel et al. 2007; Shane 2004; Toole and Czarnitzki 2009, 2010), and "informal" arrangements like technical assistance, consulting or joint publication of research papers (Cohen et al. 2002; Grimpe and Fier, 2010; Link et al. 2007; Zucker and Darby 1996, 2001). ${ }^{2}$

Related research has hence studied extensively (i) the effects of academia on private sector innovation through knowledge transfer and research collaborations and (ii) the impact of general researcher mobility on innovation. By contrast, little is known about the specific effects of scientist mobility from universities on private sector innovation. It is here where we aim to add to existing literature: we study the effects of hiring R\&D workers from universities on private sector innovation. We investigate the extent to which individuals with a science or engineering degree who join a private firm after having stayed with a university after graduation ("university researchers") contribute to the innovative output of the firm they join. We also consider the effects of individuals who have recently completed a science or engineering degree and join a private firm after graduation ("recent graduates"). We contrast these effects with

\footnotetext{
${ }^{1}$ Edler et al. (2008) provide a review of the recent literature on the international dimension of researcher mobility and provide empirical evidence that is based on German survey data.

${ }^{2}$ Canidio (2010) derives a formal theoretical model for the sorting of scientists into university and industry employees that explains why returns to R\&D decrease in firm size. For university research he finds that better researchers work at larger university research laboratories.
} 
those stemming from R\&D workers who either join from another firm ("firm joiners") or stay with their employer ("stayers"). Our theoretical framework is the "scientific and technical human capital approach" due to Bozeman et al. (2001), from which we derive three empirically testable hypotheses.

What this paper does not do, however, is to compare different means of publicprivate knowledge transfer mechanisms to one another as in Cohen et al. (2002). While we hence cannot provide managerial implications for the appropriate choice of knowledge transfer mechanism - as Cohen et al. (2002) are able to do - we can derive managerial implications with respect to optimal hiring decisions of $R \& D$ workers.

We are not the first to study the mobility of academic researchers. The existing "prior art" does, however, focus on "star" scientists and/or a particular industrial area (Almeida and Kogut 1999; Porter Liebeskind et al. 1996; Rosenkopf and Almeida 2003; Zucker and Darby 1996, 2001; Zucker et al. 1998, 2002a, 2002b); suffers from very small and possibly highly selected samples (Herrera et al. 2010; Zellner 2003); does not study the effect of scientist mobility on firm performance (Zellner 2003; Zucker et al. 2002), or does not compare the relative contributions of different types of mobile and immobile labor to one another (Cohen et al. 2002; Dietz and Bozeman 2005). Section 2 provides an overview of the literature most closely related to our paper.

We use a unique register data set on the entire population of Danish firms and their employees that covers the period 1999 to 2004. We link this data to the number of patent applications of each firm at the European Patent Office (EPO) - our measure of innovation - as well as to balance sheet data. Our analysis focuses on firms which employ at least one $R \& D$ employee since these firms are most likely to produce any patents. It is based on 16,531 observations on 5,714 firms.

Our main findings are as follows: university researchers joining a private sector firm have the largest impact on the new employer's patent counts. An increase in the number of individuals from that skill group is related to an expected increase in current citations-weighted patent counts by 0.090 for an average firm. This figure may seem small but needs to be interpreted against the background that as many as 86.6 percent of the $R \& D$ active firms we consider do not hire any additional workers of that skill group in a given year. We find that recent university graduates are second most effective in producing patents, with one additional graduate adding on average 0.040 patents to the current patent stock. This group of workers hence contributes slightly more than joiners from other firms, who add on average 0.039 patents, a difference that is not statistically significant. Stayers contribute comparatively little to patenting activity. The patent productivity effects of each skill group are considerably larger once 
we consider a firm with characteristics similar to the average firm that patented prior to 1999, the beginning of our data period. For such a firm, one additional joiner from university research adds 0.212 patents. Firm joiners add 0.093 patents and recent graduates contribute 0.095 patent applications.

These results suggest that there are other mechanisms at work through which academic research spurs private sector innovation in addition to technology transfers between universities and the private sector that has been considered in the literature up to now. In fact, one may consider the results we find as evidence for the existence of more directly measured research spillovers from universities to the private sector. Existing research measures public-private research spillovers in a rather indirect way, mostly by geographical or "technological" distance (proxied by differences in patent portfolios or patent citations patterns). These studies include Acs et al. (1992), Adams (1990), Audretsch and Stephan (1996), Anselin et al. (1997), Czarnitzki et al. (2009a), Griliches (1992), Jaffe (1989) and Mansfield (1995).

Moreover, given our descriptive results, which show that recent university graduates and university researchers receive lower wage rates than the more experienced employees hired from other private sector firms, our results suggest a rationale for focusing recruiting activities on university researchers and recent graduates rather than attracting $R \& D$ workers from competitors. We also find that the contribution of academic hirings as well as that of hirings from industry writes off over time, which in turn calls for activities promoting the formal and informal knowledge exchange between public and private researchers.

The remainder of this paper is organized as follows: Section 2 reviews the related literature. Section 3 presents the theoretical framework of our study and derives our hypotheses. Section 4 discusses our data set and defines our variables. Section 5 lays out our empirical strategy. Section 6 discusses our results whereas section 7 provides the managerial implications. Section 8 concludes.

\section{Related studies}

While we believe we are the first to analyze the differential effects of mobility of R\&D workers with different employment histories on industrial innovation, we are not the first to study the mobility of scientists in general.

In a study most closely related to ours, Cohen et al. (2002) use business survey data on large US firms that were asked to self-assess the importance of alternative sources of knowledge for own innovative activity. They show that the main channels through which public research knowledge disseminates to industry are published research papers, formal and informal public-private gatherings, as well as consulting. 
The mobility of scientists to industry plays a subordinate role according to their data. However, it is important to note that Cohen et al. (2002) compare different types of public/private knowledge transfer mechanisms, among them the mobility of university scientists, whereas we study the effects of that type of mobility in much greater detail.

Dietz and Bozeman (2005) link the research output, measured by patents and scientific publications, of 1,200 scientists supported by important US governmental institutions to career patterns taken from the scientists' résumés. They find that scientists who have never left academia publish more research papers than scientists who encountered spells of industry employment. By contrast, patent productivity appears to be correlated with public-private sector transitions.

Two studies, Crespi et al. (2007) and Zucker et al. (2002), take one step "back" compared to the level of analysis of the present paper by analyzing the determinants of academic scientist mobility instead of its effect on firm performance. Zucker et al. (2002) investigate the determinants of scientist mobility for a sample of 327 star scientists in biotechnology. They find that scientists from academia are more likely to move if their intellectual human capital, measured in terms of citations received, increases. Crespi et al. (2007) reach similar conclusions for mobile scientists from EU public research institutions.

Other works related to ours include Herrera et al. (2010) and the descriptive study by Zellner (2003). Zellner uses survey data on 214 scientists who had been employed at a leading German public research institution but have since joined a private sector employer. They were asked to self-assess how important the different types of knowledge acquired at the research institution are for their present private sector job. Zellner (2003) shows that researchers rate the broader "how to" skills to be more important than the more narrow research-specific knowledge. His paper, however, does not analyze the effects of scientist mobility on industrial innovation.

Herrera et al. (2010) use data on 35 firms who have self-reported to have hired at least one worker from the "public R\&D system" and compare their performance to similar firms who did not hire any of these workers. They find that firms who did hire workers from science outperform the control group of firms on many dimensions. The study does not, however, (i) compare different types of hires from universities, (ii) compare the effectiveness of hires from universities compared to hires from industry (or any other potentially relevant type of labor) or (iii) consider the number of hires (it simply uses a binary indicator for hire/no hire). Moreover, the control group firms have much lower levels of $R \& D$ on average, which may explain the key finding of positive performance effects.

Finally, Cassiman et al. (2011) conduct a detailed case study for a Belgian pub- 
licly subsidized research joint venture in nanotechnology, IMEC. They show that hiring workers who have previously been employed at IMEC does not generally lead to significant changes in the innovative output of the hiring firms. Instead, active participation in the research joint venture ("buying a spot in the lab") does indeed lead to economically and statistically significant positive effects on industrial innovation.

In addition, many of the papers on general researcher mobility and industrial innovation (and among them many of the most influential ones) are based on "star scientists" (e.g. Almeida and Kogut 1999; Porter Liebeskind et al. 1996; Rosenkopf and Almeida 2003; Zucker and Darby 1996, 2001; Zucker et al. 1998, 2002) or concerned with one specific industry, mostly biotechnology, nanotechnology or semiconductors (e.g. Audretsch and Stephan 1996; Cassiman et al. 2011; Corredoira and Rosenkopf 2010; Dokko and Rosenkopf 2010). In reality, however, only few firms are in the biotech or semiconductor industry, and few scientists are star scientists. We hence believe that our study of the general population of $\mathrm{R} \& \mathrm{D}$ active firms and the general population of researchers produces results that are more generalizable than the studies cited above.

\section{$3 \quad$ Theory and hypotheses}

In this section we derive three main hypotheses that we take to the data. Our point of departure is the "scientific and technical human capital approach" as first proposed by Bozeman et al. (2001) and discussed as well as extended by Boardman (2009), Bozeman and Corley (2004), Dietz and Bozeman (2005) as well as Ponomariov and Boardman (2010). The focus of this approach is the individual scientist and her individual human capital endowment.

At the core of this approach is the notion that scientific and technical human capital is "the sum of an individual researcher's professional network ties, technical knowledge and skills, and resources broadly defined" as stated by Bozeman et al. (2001, p. 636). The important point for our purposes is that any researcher's scientific and technical human capital can be augmented through labor mobility. Recombining different types of human capital is more likely to produce innovations than the mere increase in any one type, an issue that has also been previously discussed by Nahapiet and Ghoshal (1998) as well as Tsai and Ghoshal (1998). This can work in a "direct" way, for example by exposing a university scientist to the more applied stock of knowledge existing in a private sector firm, or in an "indirect" way by exposing a university scientist to new professional networks present and buildable in private sector firms. Social capital stemming from professional networks can be turned into human capital according to the scientific and technical human capital approach. The idea here is 
that professional networks can be used to seek advice, information and support from individuals within the network. This endows individuals with additional scientific and technical knowledge and hence with higher human capital.

We characterize scientists along four dimensions: (i) their stock of "scientific" (or "basic") human capital before moving from one employer to another, (ii) their stock of "technical" (or "applied") human capital before moving, (iii) their ability to recombine their human capital with the human capital present at the firm they join and (iv) their professional network. We attach labels like "high", "medium" or "low" to each characteristic for each worker group in Figure 1.

Insert Figure 1 about here.

"Scientific" knowledge which constitutes an individual's scientific human capital, is the output of research that produces new knowledge without having any particular application or use in view (OECD, 2002). This type of research is typically conducted at universities. "Technical" knowledge is the output of research primarily directed towards a specific practical aim or objective (Cassiman et al. 2008; Czarnitzki et al. 2009b; Hall et al. 2001, 2003). This distinction is important since a key driver of our hypotheses is that each of the alternative types of scientists comes with different abilities to augment and re-combine its human capital. The augmentation and recombination improves an individual's human capital, which in turn leads to greater innovative activity as argued in the scientific and technical human capital approach. ${ }^{3}$ Hoisl (2007, 2009), Giuri et al. (2007) and Väänänen (2010) document a positive relationship between human capital and innovative activity - better educated and more experienced $\mathrm{R} \& \mathrm{D}$ workers generate more innovations.

The main dimensions along which we characterize our different types of labor, university researchers, graduates, firm joiners and stayers, are the stock of technical human capital, the stock of scientific human capital, the type of the professional network workers command over and an $R \& D$ worker's ability to augment and recombine her human capital through labor mobility.

University researchers possess the highest level of recent scientific human capital (Gambardella et al. 2008; Giuri et al. 2007; Kaiser 2006). These workers are likely to bring substantial and perhaps cutting edge basic research knowledge to their new employer which is beyond that of textbooks and even beyond recently published scientific articles (Meyer-Krahmer and Schmoch 1998; Murray 2002; Kaufmann and Todtling 2001; Lam 2005). In addition, they will also know how to put this recent scientific knowledge into practice since they are endowed with the necessary tacit knowledge. They may also provide some additional technical knowledge on how to run research

\footnotetext{
${ }^{3}$ Murray (2002) provides an empirical example for the biomedicine industry.
} 
projects and how to run laboratories (Zellner 2003). They are, however, not used to private sector working habits and its focus on commercializable applied research, which is why we assume that their technical human capital is modest. Their professional network will primarily consist of fellow university scientists.

Given the comparative weakness of joiners from universities in applied research and given that a private sector firm's research agenda has a focus on applied research, university researchers have the highest chance of all skill groups to successfully augment their present human capital (primarily scientific) with complementary technical human capital through moving to a private sector employer, as first evidenced by Zucker et al. (1998). The same is true for their ability to augment their primarily science-oriented professional network by a professional network that is generated in a private sector working environment (Bozeman et al. 2001; Bozeman and Corley 2004; Dietz and Bozeman 2005). The ability to augment both professional network and own human capital is hence particularly high for university researchers.

Recent graduates also add scientific human capital to their new employer. There is, however, a likely qualitative difference between university researchers and recent graduates since the former are more likely to have performed their research independently whereas recent graduates are primarily exposed to basic research through supervised thesis work and research assistance (Behrens and Gray 2001; Bozeman and Corley 2004; Kyvik and Smeby 1994). Graduate joiners are also likely to possess less technical human capital given their more indirect exposure to research. The professional network graduates command over is likely to be the smallest of all worker groups we consider since graduates are relatively young (which we document in Subsection 4.4). The type of network will, however, not be very different from that of university researchers, given the focus on scientific research. Like university researchers, graduates appear to have a high ability to augment both their professional network and their human capital through labor mobility.

Firm joiners have already been working in an application-oriented environment before moving. They will hence add little scientific human capital but will bring in substantial technical human capital (Zucker et al. 1998) by, for example, adding in a different research agenda and possibly different "routines and habits" as pointed out by Dokko et al. (2009). ${ }^{4}$ Firm joiners will also differ from the workers employed at the firm they join with respect to their professional network. It is not the type of networks that differs - they will both be oriented towards applied research — rather their networks allow them to connect to different individuals. These differences in routines and work habits as well as in the professional networks open up possibilities

\footnotetext{
${ }^{4}$ Differences in routines and habits are extensively studied in the management literature (Almeida et al. 2003; Adkins 1995; Beyer and Hannah 2002; Gioia and Poole 1984; Higgins 2001; Rao and Drazin 2002).
} 
for re-combination due to mobility (Bozeman et al. 2001; Bozeman and Corley 2004). These possibilities are relatively low when compared to university researchers and recent graduates, however.

Stayers are likely to be similar to firm joiners with respect to their technical and scientific human capital since the only difference between either is their mobility status. Both types of workers have been employed in the private sector with its focus on applied research. They will both also command over a professional network that is similar in type. The only difference between firm joiners and stayers according to our four dimensions of differentiation is that stayers - through their very immobility - have even smaller chances to augment and re-combine their human capital than firm joiners. The literature on (inter-firm) labor mobility cited in the introduction has indeed shown that mobile workers are more important to innovative activity than immobile workers.

Obviously, any worker joining the present employer may generate possibilities for stayers to augment their knowledge as well - provided that the joiners bring in different technical or scientific human capital and professional networks. We assume, however, that the stayers' ability to augment and re-combine their human capital is substantially smaller than that of joiners because the share of joiners is much smaller than the share of stayers (compare our descriptive statistics in Subsection 4.3). There are hence fewer chances for stayers to be exposed to the new workers' knowledge than the other way around.

The following paragraphs derive empirically testable hypotheses related to the expected relative contributions of each of our four main groups of $R \& D$ workers on innovative activity. They are each based on a pairwise comparison of different scientist types.

Our first hypothesis concerns the relative contribution of firm joiners and stayers. There is no difference between the two groups of workers with respect to either their applied research stock of knowledge or their basic research stock of knowledge. What is different, however, is their ability to re-combine their respective knowledge stocks. As argued above, stayers are unlikely to be exposed to new knowledge since they do not change their working environment, while firm joiners have a much better chance of augmenting and re-combining their human capital, which in turn leads to new innovation. ${ }^{5}$ Our first hypothesis hence reads as follows:

\footnotetext{
${ }^{5}$ An additional mechanism through which stayers may add less to innovation than firm joiners is that existing employees at the firm they join may be reluctant to adopt ideas, habits and routines from the recent hire from another firm. This issue has been discussed extensively in the context of the "not invented here" syndrome (Katz and Allen 1982).
} 
Hypothesis 1: Firm joiners contribute more to innovative activity than stayers.

This first hypothesis is primarily confirmatory since this relationship has been documented by the existing literature on labor mobility (cited in the introduction).

Our second hypothesis compares joiners from university research and graduate joiners. The main differences between these two groups of $\mathrm{R} \& \mathrm{D}$ workers are that researchers possess both a higher level of scientific knowledge and a higher level of technical knowledge relative to graduates. The differences between the two groups of workers with respect to their professional networks and their abilities to augment their human capital are less pronounced. This leads us to:

Hypothesis 2: University researchers contribute more to innovative activity than recent graduates.

Our third hypothesis compares university researchers and firm joiners. When joining a firm, university researchers are expected to have an edge over firm joiners with respect to their scientific human capital and their ability to augment and re-combine their human capital. They are, however, disadvantaged compared to firm joiners in terms of their technical human capital. Weighing the relative (dis-)advantages that university researchers possess compared to firm joiners makes us conclude that:

Hypothesis 3: University researchers contribute more to innovative activity than joiners from firms.

There is a fourth comparison of scientist types for which we cannot formulate a hypothesis. It concerns the differences between recent graduates and firm joiners. Graduate joiners possess an edge over firm joiners in terms of scientific human capital, the ability to re-combine their human capital and possibly also with respect to their ability to augment their professional network. They are, however, disadvantaged in terms of applied knowledge. It is hence an empirical question if the balance tilts in favor of graduate joiners or in favor of firm joiners.

\section{Data}

In this section we discuss the data sets we use to assemble our final data set and the definitions we apply to differentiate $R \& D$ active firms from inactive ones, $R \& D$ workers from non-R\&D workers and mobile workers from immobile workers. 


\subsection{Data sets used}

\section{Patent data}

Our point of departure for the data assembly are all patent applications that were filed at the EPO by at least one Danish applicant since EPO's foundation in 1978. This data was taken from EPO's "Worldwide Patent Statistical Database" which is better known as the "PatStat" database. ${ }^{6}$ This data set is critical since our measure for innovation is patent counts. Even though patent counts are clearly imperfect proxies for true innovative activity (Arundel and Kabla 1998), they do provide a proxy for the intermediary output of $R \& D$, are representative for one specific invention (patents must refer to one single invention) and can be easily related to patent value correlates (Trajtenberg 1990). Indeed, patent counts have been extensively used in both the management literature (Almeida and Kogut 1999; Cohen and Levinthal 1989, 1990; Song et al. 2003) and the economics literature (Blundell et al. 1995; Griliches 1990; Kim and Marschke 2005).

To account for the often asserted heterogeneity in patent value (Harhoff et al. 1999; Hall et al. 2005; Lanjouw et al. 1998), we weight each patent application by one plus the number of forward citations received within a three-year period after the EPO publication using the OECD patent citation database (Webb et al. 2005). Trajtenberg (1990) was the first to show that there is a close relationship between the number of citations a patent receives ("forward citations") and the value of the underlying invention. The total number of citation-weighted patent applications in our data is 4,867. The citation-unweighted number of patent applications is 2,535.

\section{Matched employer-employee data}

We add matched employer-employee information provided to us by Statistics Denmark to our patent data. It is important to note that our data set constitutes the whole population of Danish firms and workers, not just a selected sample.

The matched employer-employee data is available from 1980 onwards. Our data ends in 2004 due to lags in reporting at the EPO and the need to track citations to a patent for a period of three years. Information on all variables at the firm level is available from 1999 onwards. A structural break in the recording of the unique firm identifier used by Statistics Denmark prevents us from using information prior to 1999.

To create our data set we first attached unique firm identifiers to each of the patent applicants in our patent data. By doing so, we were able to match 95 percent of all applicants. The unmatched ones refer to firms that went out of business before 1999. These firms would have been lost in our analysis anyway since our firm-level information only begins in 1999. Since current patent counts are the result of past

\footnotetext{
${ }^{6}$ ULR: http://www.epo.org/patents/patent-information/raw-data/test/product-14-24.html.
} 
research efforts, we lag all $R \& D$-related variables by one period as in Blundell et al. (1999). The effective starting date of the within-sample period is thus 2000, whereby 1978-99 is a period of pre-sample information on patents that will also be used in the estimation as discussed below.

With the firm identifying numbers at hand, it was a simple task to match the patent application data and the firm-level data, essentially balance sheet information. We finally match this data to our employee-level data set. The most important piece of information from that data set refers to the highest level of education attained by an individual worker and information on her current occupation. We use this information to define our population of $R \& D$ workers. The employee-level data are aggregated to the firm level before merging. That is, we consider the total number of R\&D workers for each firm in our estimations. We do not use any employee-level data for our estimation but we do use this information for descriptive analyses.

\subsection{Definitions}

\section{R\&D active firms}

We do not consider the whole population of firms in our analysis since it is very unlikely that a firm without any R\&D workers ever patents, as documented by Kaiser et al. (2008) for a similar data set. We therefore impose the following restrictions to obtain our final data set: firstly, the data is restricted to firms that have at least one $\mathrm{R} \& \mathrm{D}$ worker. $\mathrm{R} \& \mathrm{D}$ workers are individuals who are aged between 20 and 75 , hold a master's or Ph.D. degree in technical sciences, natural sciences, veterinary sciences, agricultural sciences or health sciences, and hold a job function that requires a "high" (professionals) or "intermediate" (technicians and associate professionals) level of skills. ${ }^{7}$ Secondly, we condition on firms not operating in public service (however we do consider labor mobility from that sector).

The main estimation results are based on 16,531 firm-year observations on 5,714 unique R\&D active firms. A total of 292 unique firms patented at least once within our five-year sample period between 2000 and 2004.

\section{Knowledge workers}

We separate our R\&D worker population into knowledge-intensive R\&D workers and $R \mathscr{G} D$ support workers based on the skill level of their current occupation. The first group defines persons working in positions with a high level of scientific and technological activity. They are therefore the focus of our analysis. The latter group defines

\footnotetext{
${ }^{7}$ The information on the skill level of job functions is retrieved from the International Standard Classification of Occupations (ISCO) assembled by the International Labour Office. The respective URL is: http://www.ilo.org/public/english/bureau/stat/isco/isco88/publ4.htm.
} 
persons working in positions with an intermediate level of scientific and technological activity. $R \& D$ support workers are included in our estimations as control variables and will not be discussed further in the text below.

\section{Mobility}

We further differentiate knowledge-intensive $R \& D$ workers according to mobility status. We identify their movements between non-affiliated firms and between universities and firms. The different types of workers we consider are: (i) Stayers who are employed at Firm A both at time $t$ and time $t-1$. (ii) Firm joiners who are workers employed at firm A at time $t$, but at firm B at time $t-1$. (iii) Joiners from university research are defined as workers employed in firm A at time $t$ and at a university at time $t-1$. (iv) Graduates are defined irrespective of their previous employment status; the classification only depends on the time of graduation and the field. A graduate obtains an R\&D-related education in $t-1$ and becomes employed in a knowledgeintensive position at firm A at time $t$. (v) Other joiners constitute the final group of $\mathrm{R} \& \mathrm{D}$ workers. They are employed at firm $\mathrm{A}$ at time $t$ and their employment status in $t-1$ is unknown. ${ }^{8}$ The final group of workers are the R\&D support workers who are included as a control variable only and not differentiated by mobility. Once all the relevant worker types are defined in the employee data, the employer-employee link is used to aggregate the information to firm-level and for each firm to determine the share of each R\& D worker type.

\subsection{Descriptive statistics: firm-level data}

Our dependent variable is the number of patent applications firm $i$ applies for in year $t$ weighted by the number of forward citations. Our main explanatory variables are the six different types of $R \& D$ workers summarized in the paragraph above. We additionally control for a set of variables conventionally considered as determinants of patent activity. Firstly, we include the natural logarithm of the total number of R\&D workers. Secondly, we include capital stock which we measure as the book value of physical capital. Thirdly, we include a set of sector dummies defined according to the two-digit NACE Rev.1 industrial classification. Fourthly, we control for regional effects and time-fixed effects by dummy variables. Fifthly, we also account for possible path dependence in patenting activity by including a dummy variable for having patented in $t-1$. Finally, we control for firm $i$ 's pre-sample patenting history by including the natural logarithm of firm $i$ 's patent applications prior to 1999 and by including a dummy variable for having applied for at least one pre-sample patent. We discuss

\footnotetext{
${ }^{8}$ These are persons, for example, who have been previously self-employed, have been on leave schemes, or have immigrated between $t-1$ and $t$.
} 
details of our empirical specification in Section 5 .

Table 1 presents descriptive statistics of our dependent and explanatory variables at the firm level. The table differentiates firms with pre-sample patents, i.e. firms with at least one patent application before 1999, and those without a pre-sample patent application.

The table shows that the average firm in our sample applies for 0.153 patents per year. The average number of citation-weighted patents is 0.294 , which implies that each patent in our data receives 0.92 citations on average. There are quite pronounced differences between firms with and without pre-sample patenting with respect to within-sample patenting activity: the average number of patents is more than 30 times higher for firms that have at least one patent prior to 1999 compared to a firm without such a pre-sample patent.

There is little difference between firms with and without pre-sample patents with respect to the alternative worker shares we consider and in terms of regional affiliation. At 63.1 percent, stayers constitute by far the largest group of $R \& D$ workers. Support workers follow with 16.1 percent. Joiners from the private sector make up 11.5 percent of the total current R\&D employment on average. Outside joiners and recent graduates account for about four percent of the $R \& D$ workforce each, while joiners from university research constitute the smallest employment category, with 0.8 percent of all R\&D workers belonging to that group.

The average firm in our data employs about seven R\&D workers. Firms with patenting activity prior to 1999 employ 21 R\&D workers while firms without presample patents employ about five $R \& D$ workers. Firms with pre-sample patents also possess a substantially larger capital stock and tend to be active in more technologyintensive sectors like chemicals (including biotech), machinery and electronics.

Insert Table 1 about here.

Appendix A displays a correlation matrix of our explanatory variables. It shows that the correlation between the variables is low, a finding that is also testified by a mean variance inflation factor (VIF) of 1.67 , which is well below the critical value of 10 suggested by Belsley et al. (1980).

\subsection{Descriptive statistics: employee-level}

Table 2 details the characteristics of each group of R\&D workers currently employed in a knowledge-intensive position in a private sector firm. There are a total of 95,476 observations on such individuals which we aggregate to the employer-level for our econometric analysis and the descriptive statistics discussed above. For each year an 
individual worker is present in our data, she is observed either as a joiner from one of four possible sources or as a stayer in the firm.

Comparing the age distributions across mobility groups shows that all groups of mobile workers are on average younger than stayers. Moreover, joiners from university research are younger on average than joiners from firms. Unsurprisingly, recent graduates constitute the youngest worker group. Looking at potential experience as measured by years elapsed between graduation and the current period of observation, the average experience of workers at a firm-to-firm move in our sample is around ten years, whereas moves of university researchers to private firms occur on average around six years after graduation.

Also recorded in Table 2 are the sectoral distributions of the worker-year observations. A few sectors are seen to be very important for all groups of $R \& D$ workers. The number one employer of R\&D workers, "Technical services", accounts for somewhat less than a third of the observations within each worker group. Other sectors which are important as destination sectors are "IT \& telecom" and "Chemicals". Jointly, these three sectors employ between 60 and 67 percent of all R\&D workers. Interestingly, "Chemicals", which includes biotechnology, only ranks second in terms of R\&D worker employment shares and actually comes quite close to "IT \& telecom". The sectoral distributions are remarkably similar across the different groups of workers. This reinforces our approach to not look at scientist mobility through the biotechnology lens only.

The final piece of information in Table 2 is the average annual earnings of the $R \& D$ workers. The figures are in 1,000 DKK (2000 price level). The table shows that R\&D stayers constitute the most expensive group of workers. Their median compensation is 457,000 DKK per year. Firm joiners are second most expensive with an annual wage of 419,000 DKK. Joiners from university research and other joiners receive around 370,000 DKK on average, while recent graduates are compensated with 323,000 DKK. Uncontrolled for other factors that may affect wages, the comparatively low wages university scientists receive appear to be consistent with Stern (2004).

We shall use these figures on average wage rates in Section 7.

Insert Table 2 about here.

\section{$5 \quad$ Empirical strategy}

Our empirical framework is a standard firm-level patent production function augmented by including our six alternative types of $R \& D$ workers. It also accounts for feedback from past patenting activity to present patenting activity and for both ob- 
served and unobserved firm heterogeneity.

\subsection{The patent production function}

We assume that the knowledge production function is Cobb-Douglas (Hausman et al., 1984; Blundell et al., 1995). Patent output $P$ depends on labor input $L$, capital input $K$ and a term $A$ capturing a set of additional control variables. Labor input is differentiated into joiners from firms, $L_{J}$, joiners from university research, $L_{U}$, recent graduates, $L_{G}$, other joiners, $L_{O}$, stayers, $L_{S}$ and support workers, $L_{P} ; L=L_{J}+$ $L_{U}+L_{G}+L_{O}+L_{S}+L_{P}$.

The six different types of $R \& D$ labor enter the patent production function in terms of efficiency units as in Hellerstein et al. (1999) as well as Galindo-Rueda and Haskel (2005). This enables us to estimate each labor type's relative patent productivity. We normalize the marginal patent productivities of each labor type by the marginal patent productivity of stayers, $L_{S}$, and use natural logarithms to obtain:

$$
\ln P=\ln A+\beta \ln K+\alpha \ln L+\delta_{J} s_{J}+\delta_{U} s_{U}+\delta_{G} s_{G}+\delta_{O} s_{O}+\delta_{P} s_{P},
$$

where $s_{k}$ denotes the share of labor type $k, s_{k}=L_{k} / L$, and stayers are the omitted reference category. Appendix B contains details on the derivation of our patent production function.

\subsection{Count data models}

The dependent variable is discrete and takes on values of zero or a positive integer. The appropriate econometric tool is hence a count data model. The most popular model here is the Poisson regression (Cameron and Trivedi 1998; Winkelmann 2008) with an exponential mean function as in Hausman et al. (1984).

The Poisson model assumes, however, equality between the conditional mean and the conditional variance, i.e. equi-dispersion. This assumption if often violated in patent data contexts (Blundell et al. 1995; Cincera 1997). The violation does not affect the consistency of the parameter estimates but it does affect the precision with which they are estimated. An alternative approach, which does not rely on equidispersion, is the Negative Binomial model (NegBin) which encompasses the Poisson model. Our estimation results indicate a violation of equi-dispersion, which is why we present NegBin results throughout.

\subsection{Unobserved heterogeneity}

Our specification controls for firm-specific permanent heterogeneity in patenting activity which may for example be caused by differences in R\&D management, different 
appropriability conditions of $\mathrm{R} \& \mathrm{D}$ investments, or different technological opportunities. There are two common ways to deal with this problem: fixed effects or random effects models. Random effects are not plausible in our setting since unobserved permanent heterogeneity will most likely be correlated with the regressors.

Blundell et al. (1995, 1999, 2002) suggest a method to proxy the unobserved permanent heterogeneity, the "fixed effect". Their "pre-sample mean estimator" is developed for count data models where the information on the dependent variable has a longer history than the information on the explanatory variables. This is exactly the case for our data: The patent data starts in 1978 while the firm-level information (allowing for lags) starts in 2000 only. The estimator uses the average of the dependent variable over the pre-sample period as a proxy for the correlated fixed effects for each firm. Hence the key assumption here is that the main source of unobserved permanent heterogeneity in patent productivity is reflected in the pre-sample patent stock.

The pre-sample mean estimator relies on stationarity of the dependent variable. There is, however, a strong upward trend in the number of patent applications, which is why we apply a trend adjustment of the proxy variable as suggested by Kaiser et al. (2008).

In the practical implementation of the fixed effects proxy variable, we follow Blundell et al. $(1995,1999)$ and include the natural logarithm of the pre-sample mean number of patent applications per firm. For firms without any pre-sample patent applications, we substitute an arbitrary small constant like Blundell et al. (1999). To account for this non-linear transformation, we also include a dummy variable coded 1 if the firm has at least one pre-sample patent and 0 if this is not the case.

An alternative would be to use zero-inflated count data models. These models adjust for zeros directly by modeling an additional process describing whether the firm patents or not using the Probit framework. However, this method requires firm characteristics that can be used to model the firm's decision to patent or not in the Probit regression. Further, Staub and Winkelmann (2009) show that zero-inflation models are not robust to misspecifications of the data-generating process unlike the Poisson model (if the conditional mean is correctly specified).

\subsection{State dependence}

We finally control for possible state dependence in patenting activity. Blundell et al. (1995) include firm $i$ 's discounted patent stock as an explanatory variable. We do, however, follow the approach of Crépon and Duguet (1997) and introduce state dependence by including a dummy variable for patenting activity in $t-1$ instead

of the patent stock, since this emphasizes recent patenting activity and circumvents 
collinearity problems with the fixed effects proxy variables.

\section{Results}

Table 3 presents three sets of estimation results, our baseline model where we apply our citation weights and use once-lagged labor and capital inputs, and two robustness checks. The first robustness check uses citation-unweighted patent counts while the second differs from our baseline model by using two-times lagged labor and capital inputs. We conduct the first robustness check to analyze the extent to which valueadjustments may matter. The idea behind the second robustness check is to study whether or not it takes more than one year for mobility to be reflected in patent counts.

The coefficient estimates related to the R\&D worker shares as shown in Table 3 do not translate directly into marginal effects as in OLS models. What is directly interpretable, however, is their effect on patenting activity relative to the reference group of workers, R\&D stayers. A positive coefficient on any of the five worker group shares included in the estimation indicates that the respective worker group adds more to innovation than $\mathrm{R} \& \mathrm{D}$ stayers.

In order to simplify the interpretation of our estimation results, we present marginal effects in Table 4. Marginal effects give the absolute change in the expected number of patent applications due to an increase in the number of workers from a particular skill group by one. Appendix $\mathrm{C}$ shows how to derive marginal effects for each type of labor input from the parameters of Equation (1).

\section{Main results overview}

We find that joiners from university research have by far the most positive effect on a firm's patenting activity. The related coefficient is more than twice as large as the coefficient related to the second-most productive skill groups, recent graduates and joiners from firms. By contrast, the group of other joiners and the R\&D support workers do not contribute to an extent statistically significantly different from that of R\&D stayers.

Table 4 shows that one additional joiner from university research is associated with 0.090 additional citation-weighted patents across the average of all firms. For firms with at least one patent in the time period under consideration, the effect is as much as 0.267 patents: hiring four additional university researchers relates to one additional patent application. For firms with at least one pre-sample patent the respective figure is 0.212 additional patents. Researchers with a university employment background who join a private firm hence have a substantial impact on the patenting activity of 
the firm they join. The marginal effects of other $R \& D$ joiners, $R \& D$ support workers and $R \& D$ stayers are not statistically significantly different from zero.

We devote the following paragraph to discuss our main empirical findings in the context of the hypotheses forwarded in section 3.

\section{Hypotheses testing}

Hypothesis 1 relates to the effect of mobility, stating that firm joiners contribute more to patenting activity than stayers. Our empirical evidence strongly supports the claim with the coefficient of firm joiners being positive and statistically significant $(p$ value 0.000$)$. We hence cannot reject Hypothesis 1 and by the same token, we provide evidence for the consistency of our results with earlier findings in the literature. In fact, except for the group of joiners without a known employment history, all mobile skill groups (joiners from university research, firm joiners, and recent graduates) contribute both statistically and economically more to patenting activity than R\&D stayers. This indicates that their ability to augment and re-combine their scientific and technical human capital is indeed higher than that of R\&D stayers.

$\underline{\text { Hypothesis } 2}$ compares the relative contributions of different types of mobile workers from academia by stating that joiners from university research contribute more than recent graduates. We do indeed find that the difference between the coefficients of university researchers and recent graduates is positive and statistically significant ( $p$ value 0.026$)$. Hypothesis 2 is hence supported by our results. Our finding suggests that there is a substantial contribution of the additional applied and basic knowledge that university researchers bring to the new employer relative to recent graduates.

Hypothesis 3 compares the relative contributions of joiners from university research and firm joiners. We find that the contribution of university researchers is indeed substantially larger than that of firm joiners ( $p$ value 0.013$)$. This provides empirical support for Hypothesis 3. It suggests that the ability of joiners from university research to augment and re-combine their human capital and their basic research knowledge

provides them with an edge over the superior applied research knowledge provided by firm joiners.

While we can assert that recent graduates have a marginally stronger impact on patenting than firm joiners, we do not find a statistically significant difference ( $p$ value 0.94). This suggests that the higher ability of graduates to augment and re-combine their human capital and their better command of basic research is counter-balanced by the firm joiners' superior applied research knowledge.

Insert Table 3 about here.

Insert Table 4 about here. 


\section{Other results}

Results of secondary interest are that: (i) The total number of R\&D workers and the capital stock are positively associated with patenting activity. The corresponding coefficients translate into elasticities: a one percent increase in capital stock is related to a 0.165 percent increase in the expected number of (citations-weighted) patents and a one percent increase in the number of $R \& D$ workers is associated with an increase in the expected number of patents by 0.257 percent. (ii) Past patenting activity has a substantial effect on present patenting activity. The respective coefficient estimate suggests that a firm that patented in $t-1$ is about 1.4 times more likely to patent in $t$ as well. We hence provide evidence for substantial state dependence. (iii) Likewise, an increase in the number of pre-sample patents leads to an increase in the number of contemporary patents. The related elasticity is 0.339 and hence much larger than that of capital stock and the number of $R \& D$ workers.

\section{Robustness checks}

The citation-unweighted results shown in Table 3 suggest that the effects of the different worker groups become smaller in magnitude while all other results remain fairly unchanged. This suggests that not accounting for patent value leads to an underestimation of the effects of different types of mobile workers relative to other determinants of patenting.

Similar to the citation-unweighted regressions, the twice-lagged results suggest that lagging our variables of core interest by two periods instead of one leaves all results but the ones related to the different skill groups largely unaffected. The worker group coefficient estimates generally become smaller, suggesting that the effect of the different types of labor on present patenting activity decays over time. The skill group most adversely affected by the decay are the joiners from university research. Their knowledge, so the results suggest, appears to be written off more rapidly than that of any other worker group.

\section{Alternative interpretations}

We devote this subsection to a discussion of alternative explanations for our main empirical findings.

Alternative explanations include differences in experience and education between the worker groups. If mobile workers were more experienced and better educated than immobile workers (Hypothesis 1), if the same was true for joiners from university research versus recent graduates (Hypothesis 2) and for joiners from university research versus firm joiners (Hypothesis 3), it would provide an alternative explanation for the empirical results we produced. 
We first consider differences in average experience as the time elapsed between graduation and the year of observation. Table 2 shows that stayers are more experienced than firm joiners on average (indeed more than any of the mobile worker groups). The effect of more-experienced stayers should actually work against our empirical finding. Secondly, we consider differences in education which we proxy by the average level of formal education each worker group received (Master's versus Ph.D.). Table 2 shows that there are no substantial differences in formal education between stayers and firm joiners. Our confirmation of Hypothesis 1 is therefore not driven by differences in experience or the level of education.

When comparing joiners from university research and recent graduates, we find clear differences in terms of experience and the level of formal qualification, as should be expected. However, both differences can be regarded as an integral part of the predicted differences in the amount and quality of the scientific and technical human capital accumulated by workers in either group, and thus our descriptive findings are fully consistent with Hypothesis 2. To fully maintain our interpretation, we need to argue that the differences in experience and education between joiners from university research and recent graduates are not caused by selection into pursuing a university career rather than joining a private firm upon graduation. For joiners from university research, there has been an initial selection into university employment after graduation. If the smartest people went into an academic career, this would imply a positive selection. This selection may potentially drive our finding of positive productivity differentials between recent graduates and joiners from university research. We argue, however, that it is unlikely to be the main explanation since the joiners from university research that we observe are also subjected to a second round of selection: most moves of joiners from university research to private firms occur around a level of experience associated with tenure decisions in Danish universities (three to five years after the Ph.D.). Figure 2 shows how the observed movers from university employment to the private sector are distributed by years since graduation. More than half of the moves occur within three years after graduation and moves within a five-year horizon account for more than two-thirds of the total. This timing of moves suggests that many moves from university employment to a firm result from a negative tenure decision and goes against the effect of any positive selection after graduation.

\section{Insert Figure 2 about here.}

We reach similar conclusions for Hypothesis 3. Here we observe that firm joiners are more experienced than joiners from university research on average. This effect should go in the opposite direction of our result and hence reinforces our interpretation based on the theoretical model. In terms of the level of education, there is a difference in favor 
of joiners from university research. This suggests that joiners from university research are able to accumulate more scientific and human capital. It is consistent with our interpretation that the differential effect between joiners from university research and firm joiners is driven by differences in scientific and technical human capital, a higher ability to re-combine human capital as well as social networks. These considerations all support Hypothesis 3.

Finally, any differences in the sectoral composition of the destination firms of different groups of workers could be likely candidates for differences in their estimated effects on innovation in private firms as well. If, for example, all joiners from university research opted for sectors that were already particularly patent-intensive whereas firm joiners were more equally distributed across sectors, this could potentially go a long way to explaining the differences that we find. Judging from the evidence in Table 2 , however, there are no major differences between the distributions of observations across sectors for different worker groups. Within all groups, the three main destination sectors are "Technical services", "IT \& telecom", and "Chemicals". Together, these three sectors account for around 60 percent of all observations. Although there is a slight over-representation of joiners from university research in "Chemicals", it is far from being dominant in our sample and rather unlikely to explain the differences that we observe.

\section{$7 \quad$ Managerial implications}

Our estimation results show that labor mobility is an important source of innovative activity. In particular, we show that the largest gains to innovation are attributable to joiners from university research, workers with a science degree who have worked at a university after graduation. Hiring such workers goes hand in hand with a substantial increase in the number of patents applied for, at least compared to hiring any other type of worker we consider.

In this way, we show that the transfer of knowledge between universities and firms does not work through formal research cooperations and joint research projects only, as has been extensively studied in the literature up to now. Indeed, the public-private transfer of knowledge goes beyond such agreements, as the mobility of university researchers and recent graduates has an economically sizeable and statistically highly significant effect on the innovative activity of private firms.

Joiners from university research and graduates have an advantage over firm joiners and stayers in terms of scientific human capital and their ability to augment and recombine their superior scientific human capital with the more applied technical human capital of workers employed at private sector firms. These positive factors outweigh 
their relative disadvantage in technical human capital compared to firm joiners and stayers. The econometric evidence we provide shows that the balance between the pros and cons of hiring individuals with a public research background is positive. Both recent graduates and joiners from university research contribute more to patenting activity than do workers who have been with a firm for more than one year.

By contrast, the contribution of R\&D stayers is small in both absolute and relative terms, which suggests that firms need to devise strategies to keep their stock of workers up to date regarding recent developments in science and engineering. These strategies could comprise leave schemes and exchange programs between academia and the private sector, workshops that bring together academia and business, as well as other initiatives that facilitate the exchange of knowledge between academia and industry.

The need for such strategies is underscored by our finding that even the contribution of joiners from university research starts to decay fairly rapidly. Our estimation results suggest that even though they remain positive and substantial, the contributions of the different types of mobile and immobile workers already start to decrease just two years after they have been hired.

Obviously, hiring workers from academia also helps to mitigate the adverse effects of knowledge decay. The new hires are likely to transfer their tacit and codified knowledge to fellow workers, who thereby move their stock of scientific and technical human capital closer to the current knowledge frontier. The interchange of established and new workers may in fact improve the productivity of the new hires as well since there may be complementarities between both types of workers - the productivity of new hires increases in the number of workers with experience in the firm and vice versa. Such complementarities may also explain why there is not even more mobility among scientists - despite our finding that the direct contribution to patenting activity of stayers is much lower than that of mobile workers. This issue relates to the presence of "endogenous absorptive capacity" (Arora and Gambardella 1990, 1994; Cockburn and Henderson 1998; Cohen and Levinthal 1989, 1990; Fabrizio 2009; Gambardella 1992; Hussinger 2010; Veugelers 1997; Zahra and George 2002), a topic we leave for further research. We expect absorptive capacity to be present in our context since labor mobility should have been even higher if this were not an issue. If it existed it would, however, downward bias our estimated marginal effects for any type of worker compared to stayers.

A final issue relevant for the management of innovation is that hiring university researchers and recent graduates is associated with substantially lower wage costs than hiring workers from other private sector firms. Taking our estimates at face value and 
combining them with median annual earnings for the different types of R\&D workers suggests that the cheapest way of boosting innovative activity is to hire university researchers. For the average firm, it takes eleven joiners from university research to generate one additional (citations-weighted) patent application. The total annual earnings of these workers is 4.1 mio. DKK on average. By contrast, generating one additional patent by hiring firm joiners costs 10.7 mio. DKK for the average firm. These figures are substantially smaller for firms with pre-sample patents. For these firms it takes five joiners from university research or eleven firm joiners to produce one additional patent application. The related labor costs are 1.7 mio. DKK and 4.5 mio. DKK, respectively.

How do these labor costs relate to patent value? Using data from the Danish part of the European "PatVal" survey, Kaiser (2006) documents that 60.8 percent of the patents are evaluated as being worth more than 0.8 mio. DKK by their own inventors. As many as 42.7 percent of the patents in the Danish PatVal data are worth more than 2.3 mio. DKK and 28.1 percent are valued at more than 7.6 mio. DKK. Comparing these value estimates to the associated costs of generating a patentable invention through hirings suggests that investing in human capital may indeed be worthwhile, in particular for firms with prior patenting experience.

\section{Conclusions}

This paper analyzes the relative contribution that recent graduates and joiners from university research make to the innovative activity of the private firms they join after their spell in academia. Our research hence looks at a mechanism of knowledge transfer between universities and the private sector that goes beyond formal public-private cooperations that the literature has studied so well. We also add to the literature on labor mobility by investigating a new type of mobility, namely that between academia and industry.

We use the population of Danish firms - 5,714 firms observed over a period of five years - that employ R\&D workers to link the impact that different types of labor have on the number of annual patent applications at the European Patent Office. Our econometric analysis accounts for unobserved time-invariant heterogeneity ("fixed effects") and the effects of past patenting on present patenting ("state dependence").

Our point of departure is a theoretical framework where we balance differences in scientific and technical human capital, access to and type of professional networks and an individual's ability to augment her human capital through moving to a different working environment.

We show that joiners from university research contribute most substantially to the 
patenting activity of the firm they join. Hiring four additional joiners from university research is associated with one additional (citations-weighted) patent application on average across firms with previous patenting activity. Recent university graduates and workers hired from other firms also make substantial contributions. One additional worker of either type increases the number of patents by 0.1 per year. By contrast, the contribution of immobile workers is small. The latter finding, in combination with our result that the impact of any type of worker on patenting activity decays fairly rapidly, suggests a scope for innovation management practices that helps research workers to stay on top of the recent developments in science and engineering.

The fact that joiners from university research and recent graduates receive considerably lower wage rates than workers hired from firms implies that hiring individuals formerly employed in academia may actually be a cost-effective way of boosting a firm's own innovative performance.

This research has ignored potential complementarities between different types of labor. It may well be true that the contribution of recent graduates and joiners from university research increases in the number of workers already employed in the firm. We leave that question for further research. 
Figure 1: Hypotheses derivation

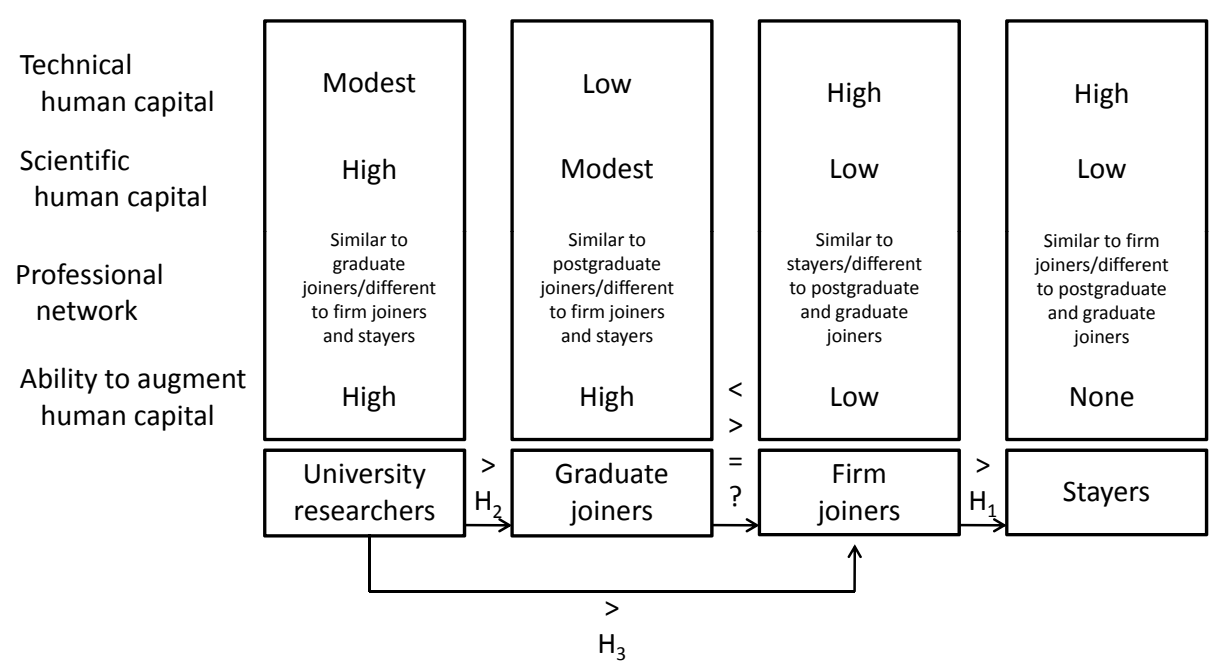

Figure 1 visualizes our three hypotheses and characterizes the four different types of workers we consider. 
Figure 2: Years elapsed since graduation for university joiners

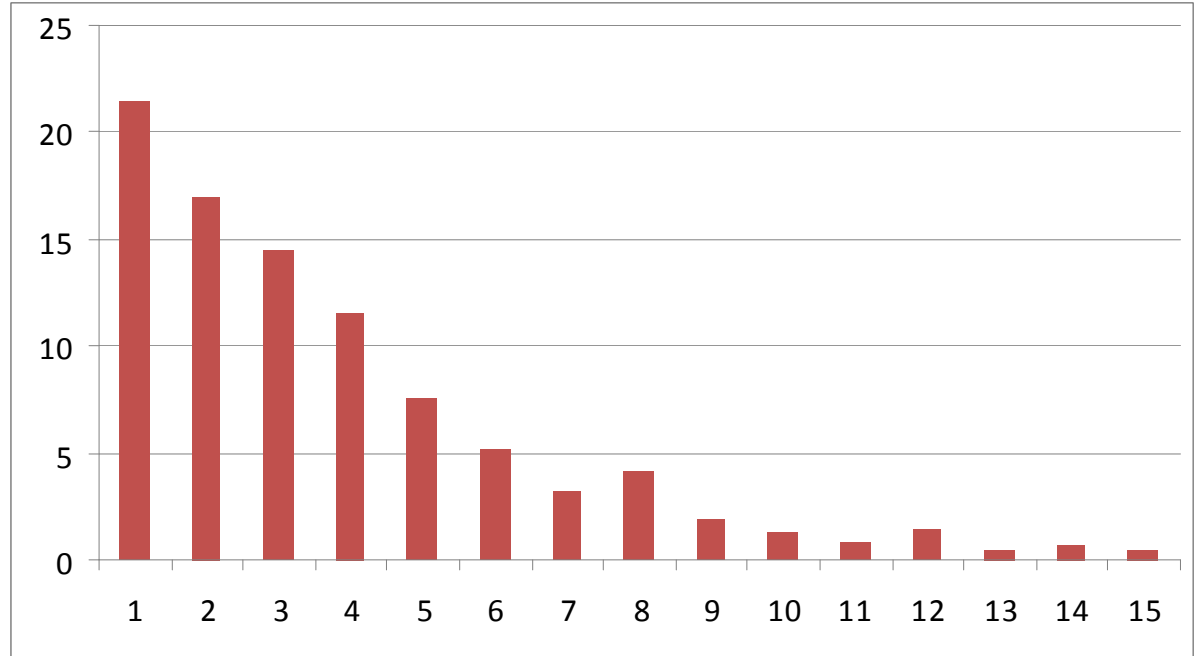

Figure 2 shows how the observed movers from university employment to the private sector are distributed by years since graduation. Reading example: 8.5 percent of moves happen more than 15 years after graduation. 
Table 1: Descriptive statistics on firms

\begin{tabular}{|c|c|c|c|c|c|c|}
\hline & \multicolumn{2}{|c|}{$\begin{array}{c}\text { All } \\
\text { observations }\end{array}$} & \multicolumn{2}{|c|}{$\begin{array}{c}\text { Without } \\
\text { pre-sample patents }\end{array}$} & \multicolumn{2}{|c|}{$\begin{array}{c}\text { With } \\
\text { pre-sample patents }\end{array}$} \\
\hline & Mean & SD & Mean & & Mean & SD \\
\hline \multicolumn{7}{|l|}{ Dependent variable } \\
\hline$\#$ patent appl. $t$ & 0.153 & 1.824 & 0.034 & 0.873 & 1.143 & 4.846 \\
\hline \# patent appl. $t$ citation weighted & 0.294 & 4.375 & 0.060 & 1.653 & 2.239 & 12.282 \\
\hline Dummy patent $t-1$ & 0.039 & - & 0.010 & - & 0.284 & - \\
\hline \multicolumn{7}{|l|}{ R\&D worker shares } \\
\hline Share stayers & 0.631 & 0.416 & 0.631 & 0.422 & 0.637 & 0.361 \\
\hline Share joiners from firms & 0.115 & 0.267 & 0.117 & 0.272 & 0.101 & 0.218 \\
\hline Share joiners from university research & 0.008 & 0.072 & 0.008 & 0.073 & 0.012 & 0.065 \\
\hline Share graduates & 0.040 & 0.160 & 0.041 & 0.165 & 0.035 & 0.113 \\
\hline Share other joiners & 0.044 & 0.178 & 0.046 & 0.184 & 0.023 & 0.111 \\
\hline Share support & 0.161 & 0.331 & 0.157 & 0.332 & 0.192 & 0.318 \\
\hline \multicolumn{7}{|l|}{ Capital and R\&D labor } \\
\hline Capital stock (in mio. DKK) & 170 & 2,040 & 118 & 1,860 & 596 & 3,140 \\
\hline Total R\&D workers & 6.594 & 33.047 & 4.821 & 18.502 & 21.282 & 84.045 \\
\hline \multicolumn{7}{|l|}{ Year dummies } \\
\hline 2000 & 0.214 & - & 0.214 & - & 0.218 & - \\
\hline 2001 & 0.199 & - & 0.199 & - & 0.206 & - \\
\hline 2002 & 0.202 & - & 0.202 & - & 0.202 & - \\
\hline 2003 & 0.195 & - & 0.195 & - & 0.194 & - \\
\hline 2004 & 0.190 & - & 0.191 & - & 0.181 & - \\
\hline \multicolumn{7}{|l|}{ Sector dummies } \\
\hline Farm \& food & 0.024 & - & 0.024 & - & 0.026 & - \\
\hline Textiles \& paper & 0.030 & - & 0.030 & - & 0.031 & - \\
\hline Chemicals & 0.024 & - & 0.018 & - & 0.071 & - \\
\hline Plastic \& glass & 0.019 & - & 0.012 & - & 0.069 & - \\
\hline Metals & 0.021 & - & 0.018 & - & 0.051 & - \\
\hline Machinery & 0.042 & - & 0.025 & - & 0.190 & - \\
\hline Electronics & 0.030 & - & 0.024 & - & 0.079 & - \\
\hline Instruments & 0.025 & - & 0.018 & - & 0.081 & - \\
\hline Gross \& retail trade & 0.196 & - & 0.209 & - & 0.088 & - \\
\hline Vehicles & 0.005 & - & 0.004 & - & 0.017 & - \\
\hline Furniture & 0.012 & - & 0.011 & - & 0.018 & - \\
\hline IT \& telecom & 0.121 & - & 0.131 & - & 0.046 & - \\
\hline Technical services & 0.249 & - & 0.258 & - & 0.172 & - \\
\hline Business-related services & 0.137 & - & 0.149 & - & 0.039 & - \\
\hline Other & 0.065 & - & 0.070 & - & 0.025 & - \\
\hline \multicolumn{7}{|l|}{ Region dummies } \\
\hline Capital & 0.529 & - & 0.536 & - & 0.471 & - \\
\hline Zealand & 0.081 & - & 0.082 & - & 0.072 & - \\
\hline Southern & 0.145 & - & 0.141 & - & 0.181 & - \\
\hline Central & 0.172 & - & 0.171 & - & 0.176 & - \\
\hline Northern & 0.073 & - & 0.070 & - & 0.099 & - \\
\hline \multicolumn{7}{|l|}{ Pre-sample variables } \\
\hline 100 times \# pre-sample patents & 0.018 & 0.282 & 0.000 & 0.000 & 0.157 & 0.846 \\
\hline Dummy pre-sample patents & 0.108 & - & 0.000 & - & 1.000 & - \\
\hline \# observations & 16,531 & & 14,750 & & 1,781 & \\
\hline
\end{tabular}

Table 1 displays descriptive statistics for the entire set of observations, for observations on firms with a pre-sample patent and for those without a pre-sample patent. "SD" denotes the respective standard deviation. 
Table 2: Descriptive statistics for R\&D workers

\begin{tabular}{|c|c|c|c|c|c|}
\hline & $\begin{array}{c}\text { Joiners } \\
\text { from firms }\end{array}$ & $\begin{array}{c}\text { Joiners } \\
\text { from univ. research }\end{array}$ & $\begin{array}{c}\text { Recent } \\
\text { graduates }\end{array}$ & $\begin{array}{l}\text { Other } \\
\text { Joiners }\end{array}$ & Stayers \\
\hline $\begin{array}{l}\text { Number of Observations } \\
\text { Age (Years) }\end{array}$ & 10,363 & 934 & 4,354 & 3,055 & 76,770 \\
\hline 10th percentile & 29.0 & 28.0 & 25.0 & 29.0 & 30.0 \\
\hline Median & 36.0 & 32.0 & 28.0 & 36.0 & 39.0 \\
\hline Mean & 37.6 & 34.2 & 28.8 & 38.4 & 40.8 \\
\hline 90th percentile & 49.0 & 44.0 & 34.0 & 52.0 & 55.0 \\
\hline \multicolumn{6}{|c|}{ Time Since Graduation (Years) } \\
\hline 10th percentile & 2.0 & 1.0 & 0.0 & 2.0 & 3.0 \\
\hline Median & 7.0 & 3.0 & 0.0 & 7.0 & 11.0 \\
\hline Mean & 9.7 & 5.5 & 0.3 & 9.9 & 13.1 \\
\hline 90th percentile & 21.0 & 13.0 & 1.0 & 23.0 & 28.0 \\
\hline \multicolumn{6}{|c|}{ Formal Qualifications (Percent) } \\
\hline Master's level & 91.1 & 64.5 & 87.9 & 92.7 & 90.0 \\
\hline Ph.D. level & 8.9 & 35.5 & 12.1 & 7.3 & 10.0 \\
\hline \multicolumn{6}{|c|}{ Sectoral Distribution (Percent) } \\
\hline Farm \& food & 1.8 & 2.9 & 2.1 & 2.2 & 2.5 \\
\hline Textiles \& paper & 1.1 & 1.3 & 1.0 & 1.9 & 1.2 \\
\hline Chemicals & 16.0 & 22.1 & 15.7 & 13.0 & 15.9 \\
\hline Plastic \& glass & 1.4 & 1.7 & 1.4 & 1.1 & 1.3 \\
\hline Metals & 0.6 & 0.8 & 0.6 & 0.6 & 0.6 \\
\hline Machinery & 2.6 & 3.6 & 4.2 & 2.8 & 4.0 \\
\hline Electronics & 3.3 & 3.9 & 3.8 & 2.5 & 2.8 \\
\hline Instruments & 2.8 & 4.0 & 2.8 & 1.8 & 2.9 \\
\hline Gross \& retail trade & 10.5 & 6.4 & 9.3 & 10.1 & 10.5 \\
\hline Vehicles & 0.3 & 0.0 & 0.3 & 0.2 & 0.5 \\
\hline Furniture & 0.4 & 0.6 & 0.3 & 0.5 & 0.4 \\
\hline IT \& telecom & 17.4 & 12.5 & 14.7 & 13.9 & 14.1 \\
\hline Technical services & 29.3 & 32.1 & 32.9 & 32.9 & 32.9 \\
\hline Business-related services & 8.6 & 5.6 & 6.4 & 9.5 & 5.8 \\
\hline Other & 4.0 & 2.6 & 4.4 & 7.1 & 4.8 \\
\hline \multicolumn{6}{|c|}{ Annual earnings (in 1,000 DKK, indexed to the year 2000) } \\
\hline 10th percentile & 229 & 265 & 263 & 212 & 317 \\
\hline Median & 419 & 370 & 323 & 374 & 457 \\
\hline Mean & 443 & 377 & 333 & 395 & 482 \\
\hline 90th percentile & 615 & 495 & 419 & 577 & 660 \\
\hline
\end{tabular}

Table 2 displays descriptive statistics for our population of R\&D workers. The information on individual R\&D workers is aggregated to the respective employer-level for the econometric analysis and for Table 1. 
Table 3: NegBin PSME estimation results

\begin{tabular}{|c|c|c|c|c|c|c|}
\hline & \multicolumn{2}{|c|}{$\begin{array}{c}\text { Main } \\
\text { Specification }\end{array}$} & \multicolumn{2}{|c|}{$\begin{array}{l}\text { Without } \\
\text { citation } \\
\text { weights }\end{array}$} & \multicolumn{2}{|c|}{$\begin{array}{c}\text { Twice } \\
\text { lagged } \\
\text { worker shares }\end{array}$} \\
\hline & Coeff. & $p$-value & Coeff. & $p$-value & Coeff. & $p$-value \\
\hline \multicolumn{7}{|l|}{ R\&D worker shares } \\
\hline Share joiners from firms & 0.822 & 0.000 & 0.746 & 0.000 & 0.712 & 0.010 \\
\hline Share joiners from university research & 1.959 & 0.000 & 1.883 & 0.000 & 1.523 & 0.007 \\
\hline Share recent graduates & 0.847 & 0.007 & 0.781 & 0.011 & 0.813 & 0.050 \\
\hline Share other joiners & 0.267 & 0.505 & 0.260 & 0.510 & 0.702 & 0.206 \\
\hline Share support & 0.297 & 0.177 & 0.276 & 0.229 & 0.276 & 0.276 \\
\hline \multicolumn{7}{|l|}{ Capital and R\&D labor } \\
\hline $\ln ($ total $\mathrm{R} \& \mathrm{D}$ workers $)$ & 0.257 & 0.000 & 0.275 & 0.000 & 0.266 & 0.000 \\
\hline $\ln ($ capital stock $)$ & 0.165 & 0.000 & 0.166 & 0.000 & 0.161 & 0.000 \\
\hline \multicolumn{7}{|c|}{ Lagged dependent and pre-sample variables } \\
\hline Dummy patent $t-1$ & 1.394 & 0.000 & 1.425 & 0.000 & 1.447 & 0.000 \\
\hline $\ln ($ fixed effect) & 0.339 & 0.000 & 0.293 & 0.000 & 0.313 & 0.002 \\
\hline Fixed effect dummy & 0.222 & 0.466 & 0.338 & 0.166 & 0.414 & 0.314 \\
\hline Tests for joint significance & Test stat. & $p$-value & Test stat. & $p$-value & Test stat. & $p$-value \\
\hline Worker shares & 31.64 & 0.000 & 28.74 & 0.000 & 14.20 & 0.014 \\
\hline Year dummies & 5.52 & 0.238 & 4.98 & 0.290 & 9.24 & 0.026 \\
\hline Sector dummies & 53.97 & 0.000 & 57.94 & 0.000 & 36.10 & 0.001 \\
\hline Region dummies & 3.57 & 0.467 & 4.07 & 0.397 & 2.28 & 0.684 \\
\hline Pre-sample variables & 46.90 & 0.000 & 35.91 & 0.000 & 44.04 & 0.000 \\
\hline \multicolumn{7}{|l|}{ \# observations, firms and patents } \\
\hline \# observations & 16,531 & & 16,531 & & 10,585 & \\
\hline \# patents & 2,535 & & 2,535 & & 1,982 & \\
\hline \# patents citations weighted & 4,867 & & 4,867 & & 3,912 & \\
\hline \# firms & 5,714 & & 5,714 & & 3,880 & \\
\hline
\end{tabular}

Table 3 displays NegBin PSME regression results for our "main" specification that uses patent citation weights, a specification that does not use citation weights and a specification that lags worker shares by two instead of one period. Differences in the number of patents are due to citation weighting vs. non-weighting. The twice-lagged specification contains fewer observations because we lose one year of data. 
Table 4: Marginal effects

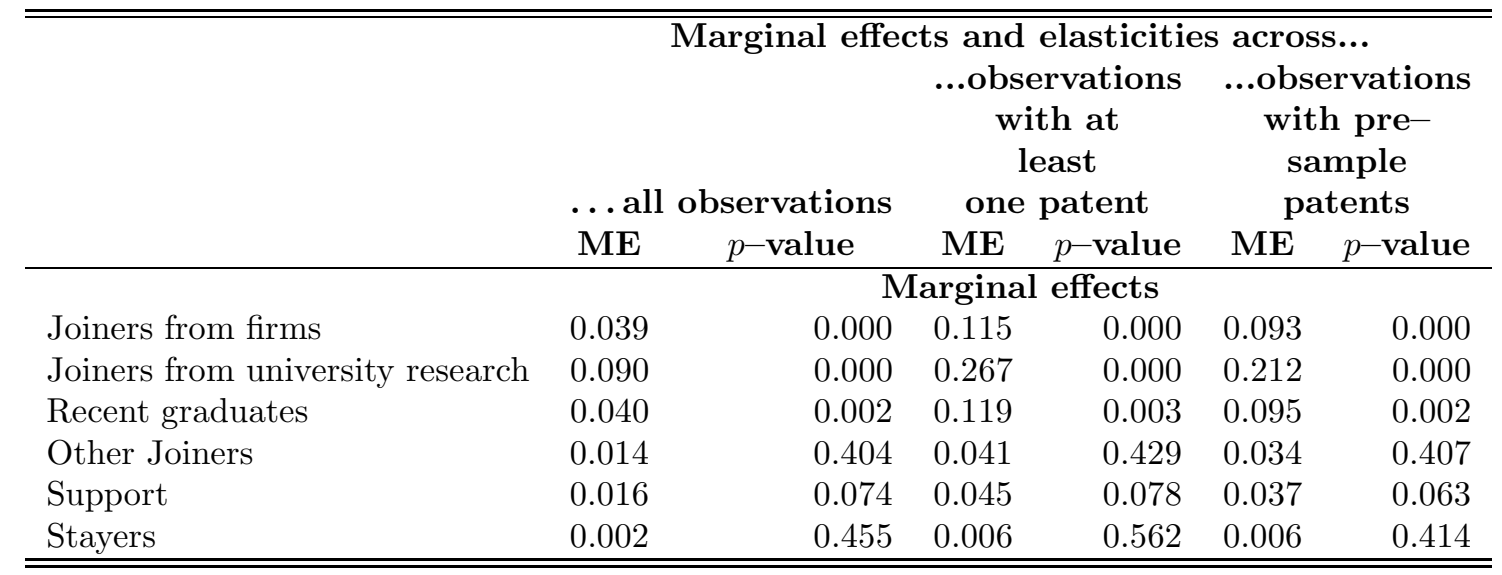

Table 4 displays marginal effects for different types of workers and across alternative types of firms. It is based on the estimation results presented as the main specification in Table 3. Marginal effects are evaluated at the means of the involved variables. Reading example: across all observations, one additional firm joiner is related to 0.039 additional patents. 


\section{References:}

Acs, Z., D.B. Audretsch and M.P. Feldman (1992), Real Effects of Academic Research: Comment, American Economic Review, 363-367.

Adams, J.D. (1990), Fundamental stocks of knowledge and productivity growth, Journal of Political Economy, 98, 673-702.

Adams, J.D., E.P. Chiang and K. Starkey (2001), Industry-University Cooperative Research Centers, The Journal of Technology Transfer 26, 73-86.

Adkins, C.L. (1995), Previous work experience and organizational socialization-A longitudinal examination. Academy of Management Journal 38(3) 839-862.

Agrawal, A. and R. Henderson (2002), Putting Patents in Context: Exploring Knowledge Transfer from MIT, Management Science 28(1), 44-60.

Allison, P.D. and J.S. Long (1990), Departmental effects on scientific productivity. American Sociology Review 55(4), 469-478.

Almeida, P. and B. Kogut (1999), Localization of Knowledge and the Mobility of Engineers in Regional Networks, Management Science 45, 905-916.

Almeida, P., G. Dokko and L. Rosenkopf (2003), Startup size and the mechanisms of external learning: Increasing opportunity and decreasing ability? Research Policy 32(2) 301-315.

Anselin, L., A. Varga and Z. Acs (1997), Local Geographic Spillovers between University Research and High Technology Innovations, Journal of Urban Economics, Elsevier 42(3), 422-448.

Arora, A. and A. Gambardella (1990), Complementarity and External linkages: the strategies of the large firms in Biotechnology, Journal of Industrial Economics, $38,361-379$.

Arora, A. and A. Gambardella (1994), The Changing Technology of Technological Change, Research Policy 23, 523-532.

Arora, A. and A. Gambardella (1994), Evaluating technological information and using it. Journal of Economic Behavior and Organization 24, 91-114.

Arundel, A. and I. Kabla (1998), What Percentage of Innovations are Patented? Empirical Estimates for European Firms, Research Policy 27, 127-141.

Audretsch, D.B. and P.E. Stephan (1996), Company-Scientist Locational Links: The Case of Biotechnology, American Economic Review 86(3), 641-652.

Behrens, T.R. and D.O. Gray (2001), Unintended consequences of cooperative research: impact of industry sponsorship on climate for academic freedom and other graduate student outcome, Research Policy 30, 179-199.

Belsley, D.A., E. Kuh and R.E. Welsh (1980), Regression Diagnostics: Identifying Influential Data and Sources of Collinearity, New York.

Beyer, J.M. and D.R. Hannah (2002), Building on the past: Enacting established personal identities in a new work setting. Organization Science 13(6), 636-652.

Blundell, R., R. Griffith and J. van Reenen (1995), Dynamic Count Data Models of Technological Innovation, The Economic Journal 105, 333-344.

Blundell, R., R. Griffith and J. van Reenen (1999), Market Share, Market Value and Innovation in a Panel of British Manufacturing Firms, Review of Economic Studies 66, 529-554. 
Blundell, R., R. Griffith and F. Windmeijer (2002), Individual Effects and Dynamics in Count Data Models, Journal of Econometrics 108, 113-131.

Boardman, P.C. (2009), Government Centrality to University-Industry Interactions: University Research Centers and the Industry Involvement of Academic Researchers, Research Policy 38, 1505-1516.

Bozeman, B., J.S. Dietz and M. Gaughan (2001), Scientific and technical human capital: an alternative model for research evaluation, International Journal of Technology Management 22(7), 716-740.

Bozeman, B. (2000), Technology Transfer and Public Policy: A Review of Research and Theory, Research Policy 29, 627-655.

Bozeman, B. and E. Corley (2004), Scientists' Collaboration Strategies: Implications for Scientific and Technical Human Capital, Research Policy 33, 599-616.

Canidio, A. (2010), Absorptive capacity, the allocation of scientists, and firms' research productivity, Central European University working paper.

Cameron, C. and P. Trivedi (1998), The Analysis of Count Data, Cambridge University Press, New York.

Cassiman, B. and R. Veugelers (2005), R\&D Cooperation between Firms and Universities: Some empirical evidence from Belgium, International Journal of Industrial Organization 23(5-6), 355-379.

Cassiman, B., R. Veugelers and S. Arts (2010), Tracing the Effect of Links between Science and Industry: The Role of Researcher Interaction and Mobility between Firms and Research Organizations, IESE working paper.

Cassiman, B., R. Veugelers and M.P. Zuniga (2008), In Search of Performance Effects of (in)Direct Industry Science Links, Industrial and Corporate Change 17(4), 611646.

Cincera, M. (1997), Patents, R\&D, and Technological Spillovers at the Firm Level: Some Evidence from Econometric Count Models for Panel Data, Journal of Applied Econometrics 12(3), 265-80.

Clark, K. (1987), Investment in new technology and competitive advantage. In D.J. Teece (Ed.), The competitive challenge: 59-82. Grand Rapids, MI: Harper \& Row.

Cockburn, I. and R. Henderson (1998), Absorptive capacity, coauthoring behavior and the organization of research in drug discovery. Journal of Industrial Economics 46(2), 157-182.

Cohen, W.M. and D.A. Levinthal (1989), Innovation and learning: Two Faces of R\&D. Economic Journal 99, 569-596.

Cohen, W.M. and D.A. Levinthal (1990), Absorptive capacity: A new perspective on learning and innovation. Administrative Science Quarterly 35, 128-152.

Cohen, W.M., R. Nelson and J.P. Walsh (2002), Links and Impacts: The Influence of Public Research on Industrial R\&D, Management Science 48(1), 1-23.

Corredoira, R.A. and L. Rosenkopf (2010), Should Auld Acquaintance Be Forgot? The Reverse Transfer of Knowledge through Mobility Ties, Strategic Management Journal 31(2), 159-181. 
Crépon, B. and E. Duguet (1997), Estimating the Innovation Function from Patent Numbers: GMM on Count Panel Data, Journal of Applied Econometrics 12, 243-263.

Crespi, G.A., A. Geuna and B. Verspagen (2007), University IPRs and Knowledge Transfer. Is the IPR ownership model more efficient? SPRU Electronic Working Paper Series 154.

Czarnitzki, D., K. Hussinger and C. Schneider (2009a), Why challenge the ivory tower? New evidence on the basicness of academic patents, Kyklos: internationale Zeitschrift für Sozialwissenschaften 62(4), 488-499.

Czarnitzki, D., K. Kraft and S. Thorwarth (2009b), The knowledge production of "R" and "D", Economics Letters 105, 141-143.

Dietz, J.S. and B. Bozeman (2005), Academic careers, patents, and productivity: industry experience as scientific and human capital, Research Policy 34, 349-367.

Dokko, G., Social capital for hire? Mobility of technical professionals and firm influence in wireless standard committees, Organization Science 21, 677-695.

Dokko, G., S.L. Wilk and N.P. Rothbard (2009), Unpacking prior experience: How career history affects job performance, Organization Science 20(1), 51-68.

Edler, J., H. Fier and C. Grimpe (2008), International Scientist Mobility and the Locus of Technology Transfer, ZEW Discussion Papers 08-082.

Fabrizio, K. (2009), Absorptive capacity and the search for innovation. Research Policy 38(2), 255-267.

Feldman, M., I. Feller, J. Bercovitz and R. Burton (2002), Equity and the technology transfer strategies of American research universities, Management Science 48(1), 105-121.

Friedman, J. and J. Silberman (2003), University Technology Transfer: Do Incentives, Management, and Location Matter? Journal of Technology Transfer 28, 17-30.

Galindo-Rueda, F. and J. Haskel (2005), Skills, Workforce Characteristics and FirmLevel Productivity: Evidence from the Matched ABI/Employer Skills Survey, IZA discussion paper No. 1542.

Gambardella, A. (1992), Competitive advantages from in-house scientific research: the US pharmaceutical industry in the 1980s. Research Policy 21, 391-407.

Gambardella, A., D. Harhoff and B. Verspagen (2008), The Value of European Patents, European Management Review 5, 69-84.

Gioia, D.A. and P.P. Poole. (1984), Scripts in organizational behavior. Academy of Management Review 9(3) 449.

Giuri, P., M. Mariani, S. Brusoni, G. Crespi, D. Francoz, A. Gambardella, W. GarciaFontes, A. Genua, R. Gonzales, D. Harhoff, K. Hoisl, C. Lebas, A. Luzzi, L. Magazzini, L. Nesta, O. Nomaler, N. Palomeras, P. Patel, M. Romanelli and B. Verspagen (2007), Inventors and Invention Processes. Results from the PatValEU Survey, Research Policy 36(8), 1107-1127.

Griliches, Z. (1990), Patent Statistics as Economic Indicators: A Survey, Journal of Economic Literature, American Economic Association 28(4), 1661-1707.

Griliches, Z. (1992), The Search for R\&D Spillovers, Scandinavian Journal of Economics, Blackwell Publishing 94(0), 29-47. 
Grimpe, C. and H. Fier (2010), Informal University Technology Transfer: A Comparison Between the United States and Germany, Journal of Technology Transfer 35, 637-650.

Groysberg, B., L. Lee and A. Nanda (forthcoming), Can they take it with them? The portability of star knowledge workers' performance: Myth or reality? Management Science.

Hall, B.H., A.N. Link and J.T. Scott (2001), Barriers Inhibiting Industry from Partnering with Universities: Evidence from the Advanced Technology Program, Journal of Technology Transfer 26, 87-98.

Hall, B.H., A.N. Link and J.T. Scott (2003), Universities as Research Partners, Review of Economics and Statistics 85(2), 485-491.

Hall B.H., A.B. Jaffe and M. Trajtenberg (2005), Market Value and Patent Citations, RAND Journal of Economics 36, 16-38.

Harhoff, D., F. Narin, F.M. Scherer, and K. Vopel (1999), Citation Frequency and the Value of Patented Inventions, Review of Economics and Statistics 81, 511-515.

Hausman, J.A., B.H. Hall and Z. Griliches (1984), Econometric Models for Count Data with an Application to the Patents-R\&D Relationship, Econometrica 47, 909-938.

Hellerstein, J.K., D. Neumark and K.R. Troske (1999), Wages, Productivity, and Worker Characteristics: Evidence from Plant-Level Production Functions and Wage Equations, Journal of Labor Economics 17(3), 409-446.

Herrera, L., M.F. Munõz-Doyaguea and M. Nietoa (2010), Mobility of public researchers, scientific knowledge transfer, and the firm's innovation process, Journal of Business Research 63(5), 510-518.

Hicks, D., T. Breitzman, D. Olivastro and K. Hamilton (2001), The changing composition of innovative activity in the US - a portrait based on patent analysis. Research Policy 30 (4), 681-703.

Higgins, M.C. (2001), Changing careers: The effects of social context, Journal of Organizational Behaviour 22(6), 595-618.

Hoisl, K. (2007), Tracing mobile inventors - the causality between inventor mobility and inventor productivity. Research Policy 36(8), 1107-1127.

Hoisl, K. (2009), Does mobility increase the productivity of inventors? Journal of Technology Transfer 34, 212-225.

Hussinger, K. (2010), Absorptive Capacity and Post-Acquisition Inventor Productivity, Centre for European Economic Research discussion paper 10-066, Mannheim.

Jaffe, A. (1989), The Real Effects of Academic Research, American Economic Review 79 (5), 957-970.

Jensen, R.A. and M.C. Thursby (2001), Proofs and Prototypes for Sale: The Licensing of University Inventions, American Economic Review 91, 240-259.

Kaiser, U. (2006), The Value of Danish Patents - Evidence From a Survey of Inventors, Centre for Economic and Business Research Discussion Paper 2006-01.

Kaiser U., H.C. Kongsted and T. Rønde (2008), Labour Mobility and Patenting Activity, Centre for Applied Microeconomics, Copenhagen, Working Paper 200807. 
Kaufmann, A. and F. Todtling (2001), Science-industry interaction in the process of innovation: the importance of boundary-crossing between systems, Research Policy 30, 791-804.

Katz, R. and T.J. Allen (1982), Investigating the Not Invented Here (Nih) Syndrome. A Look at the Performance, Tenure, and Communication Patterns of 50 R\&D Project Groups, R\&D Management 12, 7-19.

Kim, J. and G. Marschke (2005), Labor mobility of scientists, technological diffusion, and the firm's patenting decision, RAND Journal of Economics 36(2), 298-317.

Kyvik, S. and J.-C. Smeby (1994), Teaching and research. The relationship between the supervision of graduate students and faculty research performance, Higher Education 28(2), 227-239.

Lach, S. and M. Schankerman (2004), Royalty Sharing and Technology Licensing in Universities, Journal of the European Economic Association 2, 252-264.

Lam, A. (2005), Work roles and careers of R\&D scientists in network organizations, Industrial relations 44(2), 242-275.

Lanjouw, J., A. Pakes and J. Putnam (1998), How to Count Patents and the Value of Intellectual Property: the Use of Patent Renewal and Application Data, Journal of Industrial Economics 46, 405-432.

Link, A.N., D.S. Siegel and B. Bozeman (2007), An empirical analysis of the propensity of academics to engage in informal university technology transfer, Industrial and Corporate Change 16(4), 641-655.

Link, A.N. and J.T. Scott (2005), Universities as Partners in U.S. Research Joint Ventures, Research Policy 34, 385-393.

Mahdi, S. and K. Pavitt (1997), Key national factors in the emergence of computational chemistry firms. International Journal of Innovation Management 1 (4), 355-386.

Maliranta, M., P. Mohnen and P. Rouvinen (2009), Is inter-firm labor mobility a channel of knowledge spillovers? Evidence from a linked employer-employee panel, Industrial and Corporate Change, Oxford University Press 18(6), 1161-1191.

Mansfield, E. (1991), Academic Research and Industrial Innovation, Research Policy 20(1), 1-12.

Mansfield, E. (1995), Academic Research Underlying Industrial Innovations: Sources, Characteristics, and Financing, The Review of Economics and Statistics 77, 5565.

Markus, H. and R.B. Zajonc (1985), The cognitive perspective in social psychology. G. Lindzey, E. Aronson, eds. Handbook of Social Psychology, 3rd ed. Knopf, New York.

McDaniel, M.A., F.L. Schmidt and J.E. Hunter (1988), Job experience correlates of job performance. Journal of Applied Psychology 73(2) 327-330.

Meyer-Krahmer, F. and U. Schmoch (1998), Science-based technologies: universityindustry interaction in four fields, Research Policy 27, 835-851.

Murray, F. (2002), Innovation as co-evolution of scientific and technological networks: exploring tissues engineering, Research Policy 31, 1389-1403.

Nahapiet, J. and S. Ghoshal (1998), Social capital, intellectual capital, and the organizational advantage, Academy of Management Review 23(2), 242-266. 
Narin, F., S.G. McMillan and D. Deeds (2000), An analysis of the critical role of public science in innovation: the case of biotechnology. Research Policy 29 (1), $1-8$.

OECD (2002), Frascati Manual 2002: Proposed Standard Practice for Surveys on Research and Experimental Development, OECD Paris.

Ponomariov, B.L. and P.C. Boardman (2010), Influencing Scientists' Collaboration and Productivity Patterns through New Institutions: University Research Centers and Scientific and Technical Human Capital, Research Policy 39, 613-624.

Porter, M.E. (1985), Competitive Advantage, Free Press, New York, 1985.

Porter Liebeskind, J., A.L. Oliver, L.G. Zucker and M. Brewer (1996), Social networks, Learning, and Flexibility: Sourcing Scientific Knowledge in New Biotechnology Firms, Organization Science 7(4), 428-443.

Quinones, M.A., J.K. Ford and M.S. Teachout (1995), The relationship between work experience and job performance: A conceptual and meta-analytic review. Personnel Psych. 48(4) 887-910.

Rao, H. and R. Drazin (2002), Overcoming resource constraints by recruiting talent from rivals: A study of recruitment and product innovation in the mutual fund industry 1986-1994. Acadademy of Management Journal 45(3) 491-507.

Rosenkopf, L. and P. Almeida (2003), Overcoming Local Search Through Alliances and Mobility, Management Science 49(6), 751-766.

Rothaermel, F.T., S.D. Agung and L. Jiang (2007), University entrepreneurship: a taxonomy of the literature, Industrial and Corporate Change 16(4), 691-791.

Rynes, S.L., M.O. Orlitzky and R.D. Bretz, Jr. (1997), Experienced hiring versus college recruiting: Practices and emerging trends. Personnel Psychology 50(2) 309-339.

Salter, A.J. and B.R. Martin (2001), The economic benefits of publicly funded basic research: a critical review, Research Policy 30(3), 509-532.

Saxenian, A. (1994), Regional Advantage: Culture and Competition in Silicon Valley and Route 128. Cambridge, Massachusetts: Harvard University Press.

Shane, S.A. (2004), Academic entrepreneurship: university spinoffs and wealth creation, Edward Elgar, Cheltenham.

Siegel, D.S., D. Waldman and A.N. Link (2003), Assessing the Impact of Organizational Practices on the Relative Productivity of University Technology Transfer Offices: An Exploratory Study, Research Policy 32, 27-48.

Siegel, D.S., D.A. Waldman, L.E. Atwater and A.N. Link (2004), Toward a Model of the Effective Transfer of Scientific Knowledge from Academicians to Practitioners: Qualitative Evidence from the Commercialization of University Technologies, Journal of Engineering and Technology Management 21, 115-142.

Siegel, D.S. and P. Phan (2005), Analyzing the Effectiveness of University Technology Transfer: Implications for Entrepreneurship Education, in: Liebcap, G. (ed.) Advances in the Study of Entrepreneurship, Innovation, and Economic Growth, Amsterdam, 1-38.

Singh, J. and A. Agrawal (2010), Recruiting for Ideas: How Firms Exploit the Prior Inventions of New Hires, Management Science 57(1), 129-150. 
Song, J., P. Almeida and G. Wu. (2003), Learning-by-hiring: when is mobility more likely to facilitate inter-firm knowledge transfer? Management Science 49(4), 351-365.

Staub, K. E. and R. Winkelmann (2009), Robust Estimation of Zero-inflated Count Models, University of Zurich, Working Paper No. 0908.

Stern, S. (2004), Do scientists pay to be scientists?, Management Science 50(6), 835853.

Subramaniam, M. and M.A. Youndt (2005), The influence of intellectual capital on the types of innovative capabilities, Academy of Management Journal 48(3), 450463.

Thursby, J.G. and S. Kemp (2002), Growth and Productive Efficiency of University Intellectual Property Licensing, Research Policy 31, 109-124.

Thursby, M.G. and J. Thursby (2002), Who is Selling the Ivory Tower: The Sources of Growth in University Licensing, Management Science 48, 90-104.

Toole, A.A. and D. Czarnitzki (2009), Biomedical academic entrepreneurship through the SBIR program, Journal of Economic Behavior \& Organization 63(4), 716-738.

Toole A. and D. Czarnitzki (2010), Commercializing science: Is there a university 'brain drain' from academic entrepreneurship?, Management Science 56(9), 15991614 .

Torero, M., M.R. Darby, L.G. Zucker (2001), The importance of intellectual human capital in the birth of the semiconductor industry, Management Science 48(1),

Trajtenberg, M. (1990), A Penny for Your Quotes: Patent Citations and the Value of Innovations, The Rand Journal of Economics 21, 172-187.

Tsai, W. and S. Ghoshal (1998), Social capital and value creation: the role of intrafirm networks, Academy of Management Journal 41(4), 464-476,

Väänänen, L. (2010), Human capital and incentives in the creation of inventions a study of Finnish inventors, PhD thesis Aalto University School of Economics; URL: http://helecon3.hkkk.fi/pdf/diss/a368.pdf.

Veugelers, R. (1997), Internal R\&D expenditure and external technology sourcing. Research Policy 26, 303-316.

Veugelers, R. (2006), Literature review on M\&A and R\&D. Cassiman, B. and M.G. Colombo. eds. Merger and Acquisitions - The Innovation Impact.

Webb, C., H. Dernis, D. Harhoff and K. Hoisl (2005), Analysing European and International Patent Citations: A Set of EPO Patent Database Building Blocks, STI Working Paper 2005/9, OECD.

Winkelmann, R. (2008), Econometric Analysis of Count Data, Heidelberg, New York: Springer.

Zahra, S.A. and G. George (2002), Absorptive Capacity: a review, reconceptualization and extension. Academy of Management Review 27(2), 185-203.

Zellner, C. (2003), The economic effects of basic research: evidence for embodied knowledge transfer via scientists' migration, Research Policy 32(10), 1881-1895.

Zucker, L.G. and M.R. Darby (1996), Star Scientists and Institutional Transformation: Patterns of Invention and Innovation in the Formation of the Biotechnology Industry, Proceedings of the National Academy of Sciences 93(23), 12709-12716. 
Zucker, L.G. and M.R. Darby (1998), Intellectual human capital and the birth of U.S. biotechnology enterprises, The American Economic Review 88(1), 290-306.

Zucker, L.G. and M.R. Darby (2001), Capturing Technological Opportunity Via Japan's Star Scientists: Evidence from Japanese Firms' Biotech Patents and Products, Journal of Technology Transfer 26(1/2), 37-58.

Zucker, L.G., M.R. Darby and M.B. Brewer (1998), Intellectual human capital and the birth of U.S. biotechnology enterprises, American Economic Review 88(1), 290-306.

Zucker, L.G., M.R. Darby and J.S. Armstrong (2002a), Commercializing Knowledge: University Science, Knowledge Capture, and Firm Performance in Biotechnology, Management Science 48(1), 138-153.

Zucker, L.G., M.R. Darby and M. Torero (2002b), Labor Mobility from Academe to Commerce, Journal of Labor Economics 20(3), 629-660. 


\section{Appendix A: Correlation matrix}

\begin{tabular}{lccccc}
\hline \hline & $\begin{array}{c}\text { Lag } \\
\text { patent }\end{array}$ & $\begin{array}{c}\text { J. from } \\
\text { firms }\end{array}$ & $\begin{array}{c}\text { J. from } \\
\text { univ }\end{array}$ & $\begin{array}{c}\text { J. } \\
\text { other }\end{array}$ & Grad. \\
\hline Dummy patent $t-1$ & 1 & & & & \\
Joiners from firms & 0.0059 & 1 & & & \\
Joiners from universities & 0.0271 & -0.025 & 1 & & \\
Other joiners & -0.0221 & -0.076 & -0.020 & 1 & 1 \\
Recent graduates & 0.0099 & -0.068 & -0.001 & -0.039 & 1 \\
Support & -0.0017 & -0.162 & -0.045 & -0.101 & -0.103 \\
$\ln$ (total R\&D workers) & 0.267 & -0.029 & 0.004 & -0.062 & 0.003 \\
$\ln$ (cap. stock) & 0.2066 & -0.010 & -0.019 & -0.061 & -0.042 \\
$\ln$ (fixed effect) & 0.5242 & -0.016 & -0.016 & -0.036 & -0.008 \\
Fixed effect dummy & 0.4375 & -0.018 & -0.018 & -0.040 & -0.013 \\
& & $\ln ($ total R\&D & & & FE \\
& Supp. & workers $)$ & $\ln ($ cap. stock $)$ & $\ln (F E)$ & dummy \\
\hline Support & 1 & & & & \\
$\ln$ (total R\&D workers) & -0.029 & 1 & & & \\
$\ln$ (cap. stock) & 0.168 & 0.168 & 1 & & \\
$\ln (F E)$ & 0.017 & 0.017 & 0.295 & 1 & \\
FE dummy & 0.033 & 0.033 & 0.284 & 0.924 & 1 \\
\hline \hline
\end{tabular}


Appendix B: Patent production function derivation

This appendix derives the basic patent production function, Equation (1). Recall that $\mathrm{R} \& \mathrm{D}$ employment is divided into the following six types of labor:

$$
L=L_{S}+L_{J}+L_{U}+L_{O}+L_{G}+L_{P} \Leftrightarrow L_{S}=L-L_{J}-L_{U}-L_{O}-L_{G}-L_{P} .
$$

The Cobb-Douglas patent production function can be written as:

$$
P=\exp (\ln (A)+\beta \ln (K)+\alpha \ln (Q L)),
$$

where $A$ is a vector of fixed effects proxies, state dependence terms, time, region and industry effects which are discussed in Section $4.2, K$ denotes capital and $Q L$ is the measure of $R \& D$ labor input in efficiency units (normalizing the marginal productivity of stayers):

$$
Q L=L_{S}+\gamma_{J} L_{J}+\gamma_{U} L_{U}+\gamma_{O} L_{O}+\gamma_{G} L_{G}+\gamma_{P} L_{P}
$$

To be able to apply a Cobb-Douglas function without forcing output to zero for many firms, we need to assume perfect substitution between the different types of labor input as shown by the additive separability of the labor types. As long as we assume separability between a relative homogenous set of labor inputs, $R \& D$ employment in our context, we consider this to be a reasonable assumption.

The quality-adjusted labor input can be rewritten as:

$$
\begin{aligned}
Q L & =L_{S}+\gamma_{J} L_{J}+\gamma_{U} L_{U}+\gamma_{O} L_{O}+\gamma_{G} L_{G}+\gamma_{P} L_{P} \\
& =L-L_{J}-L_{U}-L_{O}-L_{G}-L_{P}+\gamma_{J} L_{J}+\gamma_{U} L_{U}+\gamma_{O} L_{O}+\gamma_{G} L_{G}+\gamma_{P} L_{P} \\
& =L+\left(\gamma_{J}-1\right) L_{J}+\left(\gamma_{U}-1\right) L_{U}+\left(\gamma_{O}-1\right) L_{O}+\left(\gamma_{G}-1\right) L_{G}+\left(\gamma_{P}-1\right) L_{P} \\
& =L\left(1+\left(\gamma_{J}-1\right) \frac{L_{J}}{L}+\left(\gamma_{U}-1\right) \frac{L_{U}}{L}+\left(\gamma_{O}-1\right) \frac{L_{O}}{L}+\left(\gamma_{G}-1\right) \frac{L_{G}}{L}+\left(\gamma_{P}-1\right) \frac{L_{P}}{L}\right) .
\end{aligned}
$$

Using the approximation $\ln (1+x) \approx x$ for small $x$ and taking logarithm yields:

$\ln Q L=\ln (L)+\left(\gamma_{J}-1\right) \frac{L_{J}}{L}+\left(\gamma_{U}-1\right) \frac{L_{U}}{L}+\left(\gamma_{O}-1\right) \frac{L_{O}}{L}+\left(\gamma_{G}-1\right) \frac{L_{G}}{L}+\left(\gamma_{P}-1\right) \frac{L_{P}}{L}$.

Inserting $Q L$ into the production function and defining $\delta_{k}=\alpha\left(\gamma_{k}-1\right)$ leads to:

$$
\begin{aligned}
P= & \exp [\ln (A)+\beta \ln (K)+\alpha \ln (L) . \\
& \left.+\alpha\left(\left(\gamma_{J}-1\right) \frac{L_{J}}{L}+\left(\gamma_{U}-1\right) \frac{L_{U}}{L}+\left(\gamma_{O}-1\right) \frac{L_{O}}{L}+\left(\gamma_{G}-1\right) \frac{L_{G}}{L}+\left(\gamma_{P}-1\right) \frac{L_{P}}{L}\right)\right] \\
= & \exp \left[\ln (A)+\beta \ln (K)+\alpha \ln (L)+\delta_{J} \frac{L_{J}}{L}+\delta_{U} \frac{L_{U}}{L}\right. \\
& \left.+\delta_{O} \frac{L_{O}}{L}+\delta_{G} \frac{L_{G}}{L}+\delta_{P} \frac{L_{P}}{L}\right] .
\end{aligned}
$$

which corresponds to (1). 


\section{Appendix C: Calculating marginal effects}

This appendix derives the marginal effects for the main labor types. The marginal effects do not follow directly from the estimation results because of the non-linear model we apply and because each labor type enters through the total number of R\&D workers and through the labor share variables. The absolute change in the number of patent applications (weighted by citations) by adding one additional worker of a type $L_{J}$ is found by differentiating the expected number of patents (Equation (1)):

$$
\begin{aligned}
\frac{\partial E[P]}{\partial L_{J}} & =\widehat{P}\left[\alpha \frac{1}{L}+\frac{\delta_{J} L-\delta_{J} L_{J}}{L^{2}}-\frac{\delta_{U} L_{U}}{L^{2}}-\frac{\delta_{O} L_{O}}{L^{2}}-\frac{\delta_{G} L_{G}}{L^{2}}-\frac{\delta_{P} L_{P}}{L^{2}}\right] \\
& =\frac{\widehat{P}}{L}\left[\alpha+\delta_{J}-\frac{\delta_{J} L_{J}}{L}-\frac{\delta_{U} L_{U}}{L}-\frac{\delta_{O} L_{O}}{L}-\frac{\delta_{G} L_{G}}{L}-\frac{\delta_{P} L_{P}}{L}\right],
\end{aligned}
$$

$\widehat{P}$ denotes predicted values which are evaluated in mean values. The corresponding marginal effects for the remaining types follow easily. 